\title{
Extraction of $\mathrm{Ga}$ and $\mathrm{Ge}$ from zinc refinery residues in $\mathrm{H}_{2} \mathrm{C}_{2} \mathrm{O}_{4}$ solutions containing $\mathrm{H}_{2} \mathrm{O}_{2}$
}

Fupeng Liu ${ }^{\mathrm{a}}$, ZhihongLiu ${ }^{\mathrm{a}}$, Yuhu Li $^{\mathrm{a}}$, Benjamin P. Wilson ${ }^{\mathrm{b}}$, Mari Lundström ${ }^{\mathrm{b}}$

${ }^{a}$ School of Metallurgy and Environment, Central South University, Changsha 410083, China

${ }^{b}$ Department of Materials Science and Engineering, Aalto University School of Chemical Technology, Vuorimiehentie 2, 02150 Espoo, Finland

\begin{abstract}
A new oxalic acid $\left(\mathrm{H}_{2} \mathrm{C}_{2} \mathrm{O}_{4}\right)$ and hydrogen peroxide $\left(\mathrm{H}_{2} \mathrm{O}_{2}\right)$ based extraction process was developed to recover valuable metals - in particular $\mathrm{Ga}$ and $\mathrm{Ge}$ - from the zinc refinery residues. $\mathrm{H}_{2} \mathrm{C}_{2} \mathrm{O}_{4}$ and $\mathrm{H}_{2} \mathrm{O}_{2}$ leaching studies indicated that the selective leaching of metals in the residues, that primarily contain $\mathrm{Zn}, \mathrm{Cu}, \mathrm{Fe}, \mathrm{SiO}_{2}$, $\mathrm{Ga}$ and $\mathrm{Ge}$, can be achieved. Under the optimal leaching conditions $\left(\left[\mathrm{H}_{2} \mathrm{C}_{2} \mathrm{O}_{4}\right]=110\right.$ $\mathrm{g} / \mathrm{L},\left[\mathrm{H}_{2} \mathrm{O}_{2}\right]=0.12 \mathrm{~mol} / \mathrm{L}, \mathrm{L} / \mathrm{S}$ ratio $=8, \mathrm{~T}=40^{\circ} \mathrm{C}$ and $\left.\mathrm{t}=30 \mathrm{~min}\right), 99.32 \%$ of the $\mathrm{Ga}$, $98.86 \%$ of the Ge and $30.25 \%$ of the Fe were leached out, whereas the leaching of $\mathrm{Zn}$, $\mathrm{Cu}$ and $\mathrm{Si}$ only reached $0.30 \%, 0.82 \%$ and $0.43 \%$, respectively. Concerning leachate purification, $98.31 \%$ of the iron could be removed in the form of $\mathrm{FeC}_{2} \mathrm{O}_{4} \cdot 2 \mathrm{H}_{2} \mathrm{O}$ with minor losses of $\mathrm{Ga}$ and $\mathrm{Ge}(1.08 \%$ and $0.68 \%)$ using an ultrasound-assisted iron powder replacement method under optimal conditions. The $\mathrm{Ga}(99.36 \%)$ and $\mathrm{Ge}$ (99.89\%) were subsequently extracted by tri(octyl-decyl)amine (N235). After extraction, the loaded organic phase was stripped of Ga (98.91\%) and Ge (99.21\%) into separate solutions using sequential treatments of $2 \mathrm{~mol} / \mathrm{L} \mathrm{H}_{2} \mathrm{SO}_{4}$ and $4 \mathrm{~mol} / \mathrm{L}$ $\mathrm{NaOH}$ respectively. Based on these results, a process flow sheet of efficient separation and recovery of $\mathrm{Ga}$ and $\mathrm{Ge}$ is presented.
\end{abstract}

Keywords: Zinc refinery residue; Gallium; Germanium; Oxalic acid; Hydrogen peroxide; Separation 


\section{Introduction}

Owing to their use in technological and strategic applications like semiconductors, infrared optics, optical fibers, medicine and catalysis, gallium and germanium are becoming increasingly important for global industry (Schimmel et al.,2001; Tyszczuk et al., 2007; Depuydt et al., 2006; Fujiwara et al., 2003). Although gallium and germanium are often found together in nature, they generally only exist in trace amounts in many minerals, from which the extraction is not usually economically viable. Currently, gallium and germanium are mainly recovered from the metallurgical by-products of zinc, copper and aluminum refining.

The zinc sulfide concentrate that is produced from a lead and zinc mine in southern China is rich in gallium and germanium; their respective contents are both greater than $100 \mathrm{~g} / \mathrm{t}$. The concentrate is leached in a two-stage countercurrent oxygen pressure leaching process. The first stage is performed under high acidity and low temperature and oxygen pressure conditions to leach more gallium and germanium. After the leach solution is pre-neutralized with zinc calcine, zinc powder is added to the solution to replace the gallium and germanium. The resulting material - known as zinc refinery residue - usually contain between 0.2 0.5 wt.\% Ge and 0.3 - 0.4 wt.\% Ga with $\mathrm{Zn}, \mathrm{SiO}_{2}, \mathrm{Cu}, \mathrm{Fe}$ and $\mathrm{Pb}$ as the main components. As $\mathrm{Ga}$ and $\mathrm{Ge}$ are difficult to recover and separate from such compounds, currently there is no industrial process for $\mathrm{Ge}$ and Ga recovery from these types of residue.

The conventional process for treating zinc refinery residues is to recover $\mathrm{Ga}$ and $\mathrm{Ge}$ by leaching with sulfuric acid (Harbuck, 1993; Nishihama et al., 1999; Kul and Topkaya, 2008; Nusen et al., 2015; Zhang et al., 2016a). Unfortunately, this process has a major drawback as 
the large amount of silica in the residue was leached to form a silicagermanium gel, which increases the co-precipitation of Ge. The most likely reason for this is the formation of mixed $\mathrm{Ge}-\mathrm{Si}$ polymers which hydrolyze more readily than the Ge-polymers to form a germanium rich silica gel (Dutrizac et al., 1996; Efremov et al., 2002; Liang et al., 2009; Liu et al., 2016a). With longer reaction times, the losses of $\mathrm{Ga}$ and $\mathrm{Ge}$ increase and consequently, several efforts have been made to eliminate the negative influence of silicon on the recovery of $\mathrm{Ga}$ and $\mathrm{Ge}$ in sulfuric acid leaching. This has been achieved through the use of leaching assistant agents and surfactants (Liu et al., 2016a), pressure sulfuric acid leaching (Liu et al., 2016b), stepwise leaching (using sulfuric acid and hydrofluoric acid leaching sequentially) (Harbuck et al., 1989; Harbuck, 1993) and alkaline leaching (Torma, 1991; Lee et al., 1994). Nevertheless, some challenges still remain to the use of these processes on the industrial scale, for example, the enormous consumption of the leaching assistant reagents, high capital and operational costs of pressure acid leaching, the highly corrosive nature of hydrofluoric acid and subsequent difficult purification of the alkaline leaching due to the leaching of $\mathrm{Si}, \mathrm{Pb}$ and $\mathrm{Al}$. As a result, processing methods for high silica materials rich in $\mathrm{Ga}$ and Ge still need further development.

In this study, the oxalic acid leaching of high silica residue was carried out for $\mathrm{Ga}$ and Ge. Oxalic acid was utilized due to the fact that $\mathrm{Ge}$ is known to form stable complexes with di- and tricarboxylic acids, whereas Si forms much weaker complexes with these same ligands (Pokrovski et al.,1998). In addition, oxalic is also widely used as metal precipitant (Chenakin et al., 2016; Kang et al., 2010; Ni et al., 2011) and thus, a selective leaching of the residues can be achieved. Sun et al. (2012), for example, have used oxalic acid leaching to treat spent lithium-ion batteries. Oxalate is introduced as leaching reagent meanwhile as 
precipitant which leaches and precipitates cobalt from $\mathrm{LiCoO}_{2}$ and $\mathrm{CoO}$ directly, thus the efficient separation of Li and Co can be achieved. Due to the strong complexation of ferric iron and oxalate, oxalic acid is also widely used in the removal of iron from quartz ores and these results have shown that the iron removal was above $90 \%$ using oxalic acid as leaching agent (Tuncuk et al, 2016; Lee et al., 2007; Ambikadevi et al., 2000). Szymczycha-Madeja (2011) and Liu et al. (2016c) investigated the separation and recovery of Mo and $\mathrm{Ni}$ in $\mathrm{H}_{2} \mathrm{C}_{2} \mathrm{O}_{4}$ solution with $\mathrm{H}_{2} \mathrm{O}_{2}$. It was found that $\mathrm{H}_{2} \mathrm{O}_{2}$ can promote the leaching of Mo, and under optimal conditions, approximately $99.7 \%$ of Mo was leached, whilst only $1.6 \%$ of $\mathrm{Ni}$ was leached. Although there have been a number of previous studies into the effects of oxalic acid on the leaching of metals, such as Mo, Li, $\mathrm{Ni}$ and $\mathrm{Fe}$, so far there is no report related to the recovery of gallium and germanium by an oxalic acid leaching process from zinc refinery residues. The main purpose of the present work was to investigate the leaching behaviors of $\mathrm{Ga}$ and $\mathrm{Ge}$ in a solution containing both oxalic acid (as a chelating agent that is able to form soluble metal complexes) and hydrogen peroxide (as an oxidizing agent). Hydrogen peroxide was chosen not only because it is a strong oxidant but also as it is environmentally safe, with only water produced as a by-product during the sulfide oxidation process (Liu et al., 2016c; Zhang et al., 2016b; He et al., 2014; Szymczycha-Madeja, 2011).

Compared with the recovery of gallium and germanium in the sulfuric acid solution, the recovery of gallium and germanium in oxalic acid solution is more straightforward as both gallium and germanium can form stable complexes which can be effectively extracted by by tri(octyl-decyl) amine (N235). Furthermore, N235 is an amine extractant that is widely used for the extraction of complexes due to its low cost, high availability and high extraction efficiency (Fang et al., 2014; Yang et al., 2015; Chen 
et al., 2016). Nevertheless, for the recovery of $\mathrm{Ga}$ and $\mathrm{Ge}$, the removal of iron from the oxalate solution poses an additional challenge as $\mathrm{Fe}(\mathrm{III})$ is known to exist as a stable complex in oxalate solutions. The solvent extraction process (Demopoulos et al., 1993; Principe and Demopoulos, 2004, 2005; Sun et al., 2016; Mishra et al., 2010) and neutralization precipitation process (Liang et al., 2009) have previously been used for the removal of $\mathrm{Fe}$ (III) from different solutions, however, the drawbacks of these procedures can be the simultaneous co-extraction / precipitation / occlusion of $\mathrm{Ga}$ and $\mathrm{Ge}$ into the iron rich phases. As a result of this previous research, an ultrasound-assisted iron powder replacement method was proposed to remove the $\mathrm{Fe}$ in the form of $\mathrm{FeC}_{2} \mathrm{O}_{4} \cdot 2 \mathrm{H}_{2} \mathrm{O}$ from the oxalate solution.

In the purified oxalate solution, the extraction of gallium and germanium was conducted using tri(octyl-decyl) amine (N235) as an extractant and tri-butyl-phosphate (TBP) as a modifying agent. The separation of $\mathrm{Ga}$ and $\mathrm{Ge}$ from the organic phase was conducted using sulfuric acid and sodium hydroxide as stripping agents, respectively. In the current study the applicability of the proposed experimental flow sheet for the recovery of $\mathrm{Ga}$ and $\mathrm{Ge}$ and the behavior of the other elements of interest in each unit process were investigated in order verify the process validity.

\section{Experimental}

\subsection{Materials}

The zinc refinery residue investigated was obtained from the Danxia smelter in southern China and was used after drying with a vacuum drying oven (DZF-6050, Shanghai Yuezhong Instrument Co. Ltd, China), without any further pre-treatment. The contents of $\mathrm{Ga}, \mathrm{Ge}$ and other main 
elements of the interest present in the residue are shown in Table 1. The solid materials were firstly chemically dissolved, then the concentration of metal ions was analyzed by the methods listed in section 2.2.

As can be seen, the zinc refinery residue contains 0.266 wt.\% Ga and 0.363 wt.\% Ge respectively. In addition, whereas the total iron and $\mathrm{Fe}(\mathrm{II})$ content are 7.9 wt.\% and 3.7 wt.\% respectively. The silica content is observed to be relatively high $(9.14$ wt.\%), which indicates that the leaching of gallium and germanium can be challenging.

The particle size of the zinc refinery residue was determined by a wet screen analysis, which showed that approximately $76 \mathrm{wt} \%$ of the particles in the residue were $<45 \mu \mathrm{m}$ (Table 2).

From analysis of the residue XRD pattern shown in Fig. 1, it can be clearly seen that there are several diffraction peaks of metallic zinc, zinc sulfate heptahydrate, zinc ferrite and zinc silicate, whereas no diffraction peaks of other components were observed because of their low contents or amorphous states. The small amounts of zinc ferrite (1.34 wt.\%) and zinc silicate $(2.87 \mathrm{wt} . \%)$ that are seen to exist in the residue probably originate from incomplete L/S (liquid-to-solid) separation after the preneutralization step and prior to the zinc powder replacement.

\subsection{Characterization and analyses}

The residue samples were measured by a Rigaku-TTRIII X-ray diffractometer $\left(\mathrm{CuK}_{\alpha 1}, \lambda=0.15406 \mathrm{~nm}\right)$ and the potential phases present in the sample have been identified by the software of MDI Jade 6.5. The elemental content in selected spots were measured by Electron Probe Microanalyzer (EPMA) with five wavelength dispersive X-ray spectrometers (WDS), a newly developed energy dispersive X-ray spectrometer (EDS) and the analysis was performed by a JEOL JXA8230 instrument operated at $15 \mathrm{kV}$ with a $10 \mathrm{nA}$ beam current. The phase 
compositions of the $\mathrm{Ga}$ and $\mathrm{Ge}$ in the zinc refinery residue were examined by use of a chemical selective dissolution method (Liu, 1992), and the analysis methods is mainly based on the dissolution behavior of gallium and germanium species in different solvents. The zinc concentrations in the leach residues and solutions were analyzed using ethylene diamine tetraacetic acid (EDTA) titration method. The $\mathrm{SiO}_{2}$ concentrations in leach residues and solutions were determined using the silicon molybdenum blue spectrophotometry method, whereas the germanium concentrations in leach residues or solutions were examined by extraction separation - benzfluorenone spectrophotometry. The concentrations of $\mathrm{Ga}, \mathrm{Fe}, \mathrm{Cu}, \mathrm{As}$ and $\mathrm{Pb}$ in leach residues or solutions were determined by a Thermo Electron IRIS Intrepid II XSP ICP-AES spectrometer. The $\mathrm{Fe}(\mathrm{I})$ concentrations in the zinc refinery residue were analyzed by chemical dissolution - potassium dichromate method. In contrast, the $\mathrm{Fe}(\mathrm{III})$ concentrations in leachate were analyzed by a precipitation separation - EDTA titration method (Yu et al., 2004). Additionally, the oxalate ions concentrations in the leachate were studied using the potassium permanganate titration method (Gong et al., 2006). Furthermore, the leach slurry was poured into a $\Phi 100$ Buchner funnel and filtered by vacuum suction using a SHZ-D(II) water-ring pump with a vacuum degree of $0.07 \mathrm{MPa}$ in order to observe the filtration performance according to the filtration rate.

\subsection{Experimental procedure}

The oxalic acid leaching experiments were conducted in $500 \mathrm{~mL}$ round-bottom flasks, with magnetic stirring at $300 \mathrm{rpm}$, respectively. Temperature was set and controlled by a water bath (DF-101S, Gongyi Yuhua Instrument Co., China). Iron removal experiments were initially performed for $100 \mathrm{~mL}$ of the resulting leachate in $250 \mathrm{~mL}$ conical flasks, 
and the ultrasound time was set and controlled by an ultrasonic cleaner at $30{ }^{\circ} \mathrm{C}$ (KQ-2550E, Jiangsu Kunshan Ultrasonic Cleaning Instrument Co., China, $40 \mathrm{kHz}, 200 \mathrm{~W}$ ), then the sonification solution was heated at desired temperature by a water bath with mechanical stirring at $300 \mathrm{rpm}$. The amount of iron powder required is mainly determined by the content of $\mathrm{Fe}(\mathrm{III})$ concentration present in leachate after leaching. After the iron removal step, $\mathrm{Ga}$ and $\mathrm{Ge}$ present in the solution were extracted and enriched using solvent extraction. The experiments were performed using separation funnels $(125 \mathrm{~mL})$ by mixing an organic phase with the purified solution. Then, the loaded organic phase was subsequently stripped by sequential treatment by $\mathrm{H}_{2} \mathrm{SO}_{4}$ and $\mathrm{NaOH}$. After each experiment, both residue and filtrate were subsequently analyzed and the investigated parameters utilized are displayed in Table 3. In the experiment, the organic phase consisted of tri(octyl-decyl) amine N235, tributyl phosphate (TBP) and sulfonated kerosene (all provided by Shanghai Rare-earth Chemical Co., Ltd., China) as the solvent for extraction. The iron powder and other chemical reagents used were of analytical grade, and deionized water was used throughout the experiments.

\section{Results and Discussion}

\subsection{The occurrence forms of gallium and germanium}

The sample of zinc refinery residue from the Danxia smelter was investigated with EPMA to determine the occurrence states of the gallium and germanium and the results are shown in Fig. 2 and Table 4. The analysis confirms the presence of zinc sulfate with a small quantity of $\mathrm{Ga}$ and Ge (analysis point 1). Additional points also showed an increased contents of $\mathrm{Ga}$ and $\mathrm{Ge}$ for the mixtures with iron, silica gels with zinc, lead, copper, calcium sulfates and metallic zinc, respectively. 
Fig. 3 shows the distributions of $\mathrm{Ge}, \mathrm{Ga}, \mathrm{Fe}$ and $\mathrm{SiO}_{2}$ in the zinc refinery residue and the images indicate that $\mathrm{Ge}$ and $\mathrm{Ga}$ mainly coexist in the presence of $\mathrm{Fe}$ and $\mathrm{SiO}_{2}$.

Using the data listed in Table 4, the contents of $\mathrm{Ga}$ and $\mathrm{Ge}$ in the residue were determined as a function of the analogous $\mathrm{Fe}$ and $\mathrm{Si}$ contents by utilization of the following regression analyses presented in equations (1) - (4):

$$
\begin{array}{lll}
\text { pct } \mathrm{Ge}=0.1132+0.0534 \text { pct } \mathrm{Si} & \mathrm{R}=0.842 \\
\text { pct } \mathrm{Ge}=0.3061+0.0245 \text { pct } \mathrm{Fe} & \mathrm{R}=0.597 \\
\operatorname{pctGa}=0.2114+0.0321 \text { pct } \mathrm{Si} & \mathrm{R}=0.298 \\
\operatorname{pctGa}=0.1156+0.0061 \text { pct } \mathrm{Fe} & \mathrm{R}=0.078
\end{array}
$$

From the analysis it can be seen that there is a reasonably strong correlation between Ge and $\mathrm{Si}$ (as shown in Fig. 4) as well as between $\mathrm{Ge}$ and $\mathrm{Fe}$. In contrast, the same analysis demonstrates only a relatively weak correlation between $\mathrm{Ga}$ and $\mathrm{Si}$ and between $\mathrm{Ga}$ and Fe. From these results, it can be suggested that Ge is mainly co-precipitated with iron gel and silica gel in the form of $\mathrm{MeO} \cdot \mathrm{GeO}_{2}$, while $\mathrm{Ga}$ is mainly displaced by zinc powder into the metallic form and then oxidized to $\mathrm{Ga}_{2} \mathrm{O}_{3}$.

The chemical selective dissolution method was utilized in order to more accurately analyze the phases of gallium and germanium present in the residue. The results outlined in Table 5 provide additional confirmation of the results from EPMA that showed that gallium and germanium primarily exist in the forms of dissociative or combined oxides.

\subsection{Oxalic acid leaching}

As can be seen from Table 5, in addition to the dissociative or combined oxides, germanium also occurred as both metallic germanium and germanium sulfide. The small amounts of metallic germanium and 
germanium sulfide probably originate from unreacted zinc sulfide concentrate as this contains $\mathrm{Ga}$ and Ge due to incomplete L/S (liquid-tosolid) separation after the oxygen pressure leaching. Alternatively, the source can also be the conversion of sulfide in acidic solution because zinc calcine contains a small amount of sulfide. Based on the dissolution properties of germanium species, metallic germanium and sulfide are significantly more stable than other germanium species, which gives rise to the difficulties encountered when leaching germanium. In order to solve this problem, $\mathrm{H}_{2} \mathrm{O}_{2}$ was introduced as an oxidizing agent to convert the insoluble germanium species into more soluble forms. Furthermore, oxalic acid was utilized to improve both the leaching of $\mathrm{Ga}$ and $\mathrm{Ge}$ and the filtration performance of the leaching slurry.

\subsubsection{Effect of oxalic acid concentration}

The effects of oxalic acid concentration on the leaching efficiencies of $\mathrm{Ga}, \mathrm{Ge}, \mathrm{Fe}, \mathrm{Zn}, \mathrm{Cu}$ and $\mathrm{Si}$ are shown in Fig. 5. The results clearly indicate that the extraction of $\mathrm{Ga}, \mathrm{Ge}, \mathrm{Fe}$ and $\mathrm{Zn}$ are strongly dependent on the increase in the $\mathrm{H}_{2} \mathrm{C}_{2} \mathrm{O}_{4}$ concentration, but that the extraction of $\mathrm{Cu}$ and $\mathrm{Si}$ only change slightly. The main reaction in the leaching are shown in Table 6. The extraction of $\mathrm{Ga}$ and Ge increased from 75.04 to $98.89 \%$ and 37.33 to $94.19 \%$ respectively as $\mathrm{H}_{2} \mathrm{C}_{2} \mathrm{O}_{4}$ concentration increased from $40 \mathrm{~g} / \mathrm{L}$ to $110 \mathrm{~g} / \mathrm{L}$. Conversely, further increases in $\mathrm{H}_{2} \mathrm{C}_{2} \mathrm{O}_{4}$ concentration resulted in a slight decrease in the leaching of $\mathrm{Ga}$ and $\mathrm{Ge}$ probably as a result of increased Si leaching (from 0.38 to $0.56 \%$ ), which forms a silica gel that absorbs some Ga and Ge (Liang et al., 2009; Liu et al., 2016b), simultaneously resulting in a slight decrease in the slurry filtration performance $\left(860.62\right.$ to $\left.790.86 \mathrm{~L} / \mathrm{m}^{2} \cdot \mathrm{h}\right)$. Under the same conditions, the leaching of iron increased slightly from 14.38 to $32.33 \%$ with an increase in the $\mathrm{H}_{2} \mathrm{C}_{2} \mathrm{O}_{4}$ concentration from $40 \mathrm{~g} / \mathrm{L}$ to $130 \mathrm{~g} / \mathrm{L}$. The 
low leaching efficiency of iron over the investigated oxalic acid concentration range can be attributed to the simultaneous precipitation reaction of ferrous ions and oxalic acid when the complexation reaction of $\mathrm{Fe}(\mathrm{III})$ and $\mathrm{H}_{2} \mathrm{C}_{2} \mathrm{O}_{4}$ occurs, which leads to the formation of $\mathrm{FeC}_{2} \mathrm{O}_{4} \cdot 2 \mathrm{H}_{2} \mathrm{O}$. Ferrous ions in the solution can originate from the zinc refinery residues or from the reduction of $\mathrm{Fe}(\mathrm{III})$ (Taxiarchou et al., 1997; Veglio et al., 1999). In contrast, the leaching of both $\mathrm{Zn}$ and $\mathrm{Cu}$ decreased, when the acid concentration was increased from $40 \mathrm{~g} / \mathrm{L}$ to $130 \mathrm{~g} / \mathrm{L}-\mathrm{Zn}$ decreased from $13.29 \%$ to $0.26 \%$, whereas $\mathrm{Cu}$ changed from $2.31 \%$ to $0.65 \%$. This finding results from the formation of stable precipitates of $\mathrm{ZnC}_{2} \mathrm{O}_{4} \cdot 2 \mathrm{H}_{2} \mathrm{O}$ and $\mathrm{CuC}_{2} \mathrm{O}_{4}$ as demonstrated by the XRD results of the leaching residues shown in Fig. 6.

\subsubsection{Effect of leaching time}

The effect of leaching time on the recovery of $\mathrm{Ga}, \mathrm{Ge}, \mathrm{Fe}, \mathrm{Zn}, \mathrm{Cu}$ and $\mathrm{Si}$ are presented in Fig. 7. It can be seen from the results that the leaching of $\mathrm{Ga}$ and Ge were efficient and fast with $98.89 \%$ of the Ga and $94.19 \%$ of the Ge extracted within $30 \mathrm{~min}$ of the leaching with only a minor further increase observed when leaching time was further extended from 30 to $60 \mathrm{~min}$. The leaching of Fe initially increased as the leaching time changed from 10 to $20 \mathrm{~min}$ (14.55 to $32.15 \%$ ), however, this was followed by a reduction in leaching efficiency from 32.15 to $24.14 \%$ with increasing leaching time from $20 \mathrm{~min}$ to $40 \mathrm{~min}$. Nevertheless, further increases in leaching time up to 60 mins resulted in further enhancement of the amounts of Fe leached. The reason for this observed variation in the $\mathrm{Fe}$ behavior is suggested to be attributed to the formation of $\mathrm{FeC}_{2} \mathrm{O}_{4} \cdot 2 \mathrm{H}_{2} \mathrm{O}$ between 20 to $40 \mathrm{~min}$, and the oxidation of the $\mathrm{Fe}(\mathrm{II})$ in the residues by $\mathrm{H}_{2} \mathrm{O}_{2}$ and air after $40 \mathrm{~min}$. In contrast to the leaching of $\mathrm{Fe}$, in the leaching of $\mathrm{Zn}$ and $\mathrm{Cu}$ after approximately $20 \mathrm{~min}$, a continuous decrease can be observed. The leaching of Si varies only slightly between 
10 to $60 \mathrm{~min}$, which results in an improved leach slurry filtration performance in oxalic acid when compared to that obtained with sulfuric acid (Liu et al., 2016a; Liu et al., 2016b).

\subsubsection{Effect of the $L / S$ ratio}

Fig. 8 shows the effects of the liquid-to-solid (L/S) ratio on the leaching of $\mathrm{Ga}, \mathrm{Ge}, \mathrm{Fe}, \mathrm{Cu}, \mathrm{Zn}$ and $\mathrm{Si}$. The results indicate that the leaching of $\mathrm{Ga}$ and $\mathrm{Ge}$ increased from 84.21 to $98.89 \%$ and 80.95 to $94.19 \%$, respectively, as the L/S ratio increased from 4 to 8 . This change occurs as a result the presence of gallium and germanium in the leach solution in their oxyacid forms, which can combined with the cations present $\left(\mathrm{Zn}^{2+}, \mathrm{Cu}^{2+}\right.$ and $\left.\mathrm{Fe}^{2+}\right)$ and precipitate as gallate and germanate. Hence, the leaching of $\mathrm{Ga}$ and $\mathrm{Ge}$ are controlled by the solubility of gallate and germanate. In addition, the increase in the liquid to solid ratio, means that consequently increase $\mathrm{H}_{2} \mathrm{C}_{2} \mathrm{O}_{4}$ and $\mathrm{H}_{2} \mathrm{O}_{2}$ amounts in the leaching solution to participate in the reaction at a preset leaching time (Liu et al., 2016c), thus a higher L/S ratio gives rise to enhanced levels of gallium and germanium leaching.

The leaching of Fe increased slightly when the L/S increased from 4 to 12 (12.69 to 33.95\%), whereas the leaching of $\mathrm{Zn}$ and $\mathrm{Cu}$ decreased slightly ( 4.35 to $0.27 \%, 2.98$ to $0.35 \%$ ). Under the same conditions, the leaching of $\mathrm{Si}$ was observed to increase from 0.12 to $1.2 \%$ (with $\mathrm{L} / \mathrm{S}$ from 4 to 12 ), which can lead to the deterioration of the filtration performance of the leach slurry $\left(860.62\right.$ to $\left.698.45 \mathrm{~L} / \mathrm{m}^{2} \cdot \mathrm{h}\right)$ due to the formation of silica gel at higher L/S ratios (Hua et al., 2002; Harbuck, 1993; Bodas, 1996). In addition, as the concentration of $\mathrm{Ga}$ and $\mathrm{Ge}$ in the leaching solution decreased as the L/S ratio increased, an optimum L/S ratio of 8 was chosen for the subsequent experiments. 


\subsubsection{Effect of temperature}

The leaching results obtained at different temperatures $\left(20-60{ }^{\circ} \mathrm{C}\right)$ are shown in Fig. 9. As can be observed, the leaching of both $\mathrm{Ga}$ and $\mathrm{Ge}$ increased with increasing leaching temperature with a maximum of $98.89 \%$ (Ga) and $94.19 \%(\mathrm{Ge})$ reached at $40{ }^{\circ} \mathrm{C}$, respectively. Further increases in the leaching temperature resulted in a decrease in gallium and germanium leaching, which can be attributed to the thermolabile nature of $\mathrm{H}_{2} \mathrm{O}_{2}$ (Arvin and Pedersen, 2015; Zhang et al., 2016b), which causes the oxidation efficiency of $\mathrm{H}_{2} \mathrm{O}_{2}$ on insoluble substances, like $\mathrm{Ge}, \mathrm{GeS}_{2}, \mathrm{GeS}$ and $\mathrm{Ga}_{2} \mathrm{~S}_{3}$, to decrease with increased temperature. Under the same conditions, the leaching of $\mathrm{Fe}$ increased slightly when the temperature increased from $20^{\circ} \mathrm{C}$ to $60{ }^{\circ} \mathrm{C}$ (21.75 to $\left.29.15 \%\right)$, whereas the leaching of $\mathrm{Zn}, \mathrm{Cu}$ and $\mathrm{Si}$ were all below $1 \%$ over the same range. Based on these results in this work, it can be considered that the optimal temperature for leaching with oxalate and hydrogen peroxide is around $40{ }^{\circ} \mathrm{C}$.

\subsubsection{Effect of $\mathrm{H}_{2} \mathrm{O}_{2}$ concentration}

The effect of $\mathrm{H}_{2} \mathrm{O}_{2}$ concentration was examined by varying the $\mathrm{H}_{2} \mathrm{O}_{2}$ concentration from $0 \mathrm{~mol} / \mathrm{L}$ to $0.2 \mathrm{~mol} / \mathrm{L}$, as shown in Fig. 10. The results indicate that the extraction of $\mathrm{Ge}$ increased gradually with the increase of $\mathrm{H}_{2} \mathrm{O}_{2}$ concentration. The leaching of Ge reached yields of $98.86 \%$ when the $\mathrm{H}_{2} \mathrm{O}_{2}$ concentration reached $0.12 \mathrm{~mol} / \mathrm{L}$, which equates to an improvement of approximately $15 \%$ when compared to direct $\mathrm{H}_{2} \mathrm{C}_{2} \mathrm{O}_{4}$ leaching method without $\mathrm{H}_{2} \mathrm{O}_{2}$. Nonetheless, further increases in the $\mathrm{H}_{2} \mathrm{O}_{2}$ concentration, only led to a slight further acceleration in the leaching of Ge. On the other hand, the leaching of Ga only changed slightly with an increase in the $\mathrm{H}_{2} \mathrm{O}_{2}$ concentration from $0 \mathrm{~mol} / \mathrm{L}$ to $0.2 \mathrm{~mol} / \mathrm{L}$ (from 95.78 to $99.86 \%$ ). The main reason for the measured increases of $\mathrm{Ga}$ and $\mathrm{Ge}$ leaching are attributed to the oxidation reactions of $\mathrm{H}_{2} \mathrm{O}_{2}$ with insoluble materials $\left(\mathrm{Ge}, \mathrm{GeS}_{2}, \mathrm{GeS}\right.$ and $\mathrm{Ga}_{2} \mathrm{~S}_{3}$ ) and the complexation reactions of 
$\mathrm{H}_{2} \mathrm{C}_{2} \mathrm{O}_{4}$ with $\mathrm{Ga}$ and $\mathrm{Ge}$. The main oxidation reactions are expressed in Eqs. (13) - (17), and the changes in the corresponding Gibbs free energy values are listed in Table 7.

$$
\begin{aligned}
& \mathrm{GeS}_{2}+8 \mathrm{H}_{2} \mathrm{O}_{2}=\mathrm{GeO}_{2}+2 \mathrm{SO}_{4}^{2-}+4 \mathrm{H}^{+}+6 \mathrm{H}_{2} \mathrm{O} \\
& \mathrm{Ge}+2 \mathrm{H}_{2} \mathrm{O}_{2}=\mathrm{GeO}_{2}+2 \mathrm{H}_{2} \mathrm{O} \\
& \mathrm{GeS}+4 \mathrm{H}_{2} \mathrm{O}_{2}=\mathrm{GeO}+\mathrm{SO}_{4}^{2-}+2 \mathrm{H}^{+}+3 \mathrm{H}_{2} \mathrm{O} \\
& \mathrm{Ga}_{2} \mathrm{~S}_{3}+12 \mathrm{H}_{2} \mathrm{O}_{2}=\mathrm{Ga}_{2} \mathrm{O}_{3}+3 \mathrm{SO}_{4}^{2-}+6 \mathrm{H}^{+}+9 \mathrm{H}_{2} \mathrm{O} \\
& 2 \mathrm{Ga}+3 \mathrm{H}_{2} \mathrm{O}_{2}=\mathrm{Ga}_{2} \mathrm{O}_{3}+3 \mathrm{H}_{2} \mathrm{O}
\end{aligned}
$$

As shown in Table 7, the change in the Gibbs free energy for each reaction is negative at $40{ }^{\circ} \mathrm{C}$, which suggests that the insoluble elements and sulfides of gallium and germanium are thermodynamically likely to transform into the corresponding soluble oxides when $\mathrm{H}_{2} \mathrm{O}_{2}$ is introduced into the system, which effectively promotes gallium and germanium leaching. Due to the fact that this process involves the use of both a complexing agent and oxidant, part of Fe(III) in the leaching residues will also be leached through the formation of iron complexes. This is evident from the results outlined in Fig. 10, which show that the leaching of $\mathrm{Fe}$ increases from $18.15 \%$ to $31.08 \%$ as the $\mathrm{H}_{2} \mathrm{O}_{2}$ increased from $0 \mathrm{~mol} / \mathrm{L}$ to $0.2 \mathrm{~mol} / \mathrm{L}$. Under the same conditions, the leaching of $\mathrm{Cu}, \mathrm{Zn}$ and $\mathrm{Si}$ all

change only slightly with an increase in the $\mathrm{H}_{2} \mathrm{O}_{2}$ concentration from 0 $\mathrm{mol} / \mathrm{L}$ to $0.2 \mathrm{~mol} / \mathrm{L}$, with changes from 0.73 to $0.81 \%(\mathrm{Cu}), 0.14$ to $0.41 \%$ $(\mathrm{Zn})$ and 0.39 to $0.42 \%(\mathrm{Si})$, respectively.

\subsection{Removal of iron from oxalate solution}

Based on the results outlined above, the optimal leaching conditions were determined to be a $\mathrm{H}_{2} \mathrm{C}_{2} \mathrm{O}_{4}$ concentration of $110 \mathrm{~g} / \mathrm{L}$ and $a \mathrm{H}_{2} \mathrm{O}_{2}$ concentration of $0.12 \mathrm{~mol} / \mathrm{L}$ with a $\mathrm{L} / \mathrm{S}$ ratio of 8 at $40{ }^{\circ} \mathrm{C}$ for $30 \mathrm{~min}$. 
Under these optimum conditions, the leaching efficiencies of $\mathrm{Ga}, \mathrm{Ge}, \mathrm{Fe}$, $\mathrm{Zn}, \mathrm{Cu}$ and $\mathrm{Si}$ attained were $99.32 \%, 98.86 \%, 30.25 \%, 0.30 \%, 0.82 \%$ and $0.43 \%$, respectively, with a composition of $0.330 \mathrm{~g} / \mathrm{L} \mathrm{Ga}, 0.447 \mathrm{~g} / \mathrm{L} \mathrm{Ge}$, $3.010 \mathrm{~g} / \mathrm{L} \mathrm{Fe}, 0.092 \mathrm{~g} / \mathrm{L} \mathrm{Zn}, 0.056 \mathrm{~g} / \mathrm{L} \mathrm{Cu}$ and $0.023 \mathrm{~g} / \mathrm{L} \mathrm{Si}$. The XRD of leaching residues following this treatment showed that the main phases present in the leach residues were $\mathrm{ZnC}_{2} \mathrm{O}_{4} \cdot 2 \mathrm{H}_{2} \mathrm{O}, \mathrm{FeC}_{2} \mathrm{O}_{4} \cdot 2 \mathrm{H}_{2} \mathrm{O}, \mathrm{CuC}_{2} \mathrm{O}_{4}$ and $\mathrm{SiO}_{2}$, and the contents of main elements in the leaching residues are shown in Table 8. As was observed, more than $30 \%$ of the Fe was leached in the forms of iron complexes during the oxalic acid leaching, and this can have a detrimental impact on both the extraction of $\mathrm{Ga}$ and $\mathrm{Ge}$ and the recycling efficiency of the extractant in the subsequent $\mathrm{Ga}$ and Ge solvent extraction processes. In order to address this challenge, the ultrasound - assisted iron powder replacement process was adopted.

The effects of main factors (Fe/Fe(III) molar ratio, ultrasound time, water bath reaction time and water bath temperature) on the iron removal were examined with an ultrasound power of $150 \mathrm{~W}$. The results shown in Table 9 indicated that the iron removal ratio is strongly depended on the $\mathrm{Fe} / \mathrm{Fe}(\mathrm{III})$ molar ratio and ultrasound time. The iron removal ratio increased from 78.69 to $98.31 \%$ as the $\mathrm{Fe} / \mathrm{Fe}(\mathrm{III})$ ratio increased from 2 to 6 , whereas, the iron removal ratio changed only slightly with a further increase from 6 to 8 (98.31 to $99.01 \%)$. More critically however, the loss of $\mathrm{Ga}$ and $\mathrm{Ge}$ increased from 1.08 to $2.55 \%$ and 0.68 to $1.58 \%$, respectively, when the $\mathrm{Fe} / \mathrm{Fe}$ (III) ratio was increased from 6 to 8 . As a result, the optimum $\mathrm{Fe} / \mathrm{Fe}(\mathrm{III})$ ratio selected to be 6 . The main reaction is outlined in Eq. (18):

$2 \mathrm{Fe}\left(\mathrm{C}_{2} \mathrm{O}_{4}\right)^{+}+\mathrm{Fe}+\mathrm{C}_{2} \mathrm{O}_{4}^{2-}+2 \mathrm{H}_{2} \mathrm{O}=3 \mathrm{FeC}_{2} \mathrm{O}_{4} \cdot 2 \mathrm{H}_{2} \mathrm{O} \quad \log \mathrm{K}_{(298.15)}=19.86$

In addition, Table 9 also shows that the sonification is necessary for the highly efficiency iron removal. For example, the iron removal ratio can 
increase to $98.31 \%$ when an ultrasound power of $150 \mathrm{~W}$ is applied for 10 min, which equates to more than approximately $50 \%$ improvement in the iron removal when compared to that achieved without ultrasonic treatment. An increase in the water bath reaction time and temperature also aid iron removal and the crystallization of the $\mathrm{FeC}_{2} \mathrm{O}_{4} \cdot 2 \mathrm{H}_{2} \mathrm{O}$.

The optimum conditions for the maximum removal of $98.31 \%$ of the $\mathrm{Fe}$ and minimum losses of $1.08 \%$ of the $\mathrm{Ge}$ and $0.68 \%$ of the $\mathrm{Ga}$ were determined to be as follows: $\mathrm{Fe}$ (iron powder)/Fe(III) molar ratio of 6 , ultrasound power of $150 \mathrm{~W}$; ultrasound time of $10 \mathrm{~min}$; ultrasound temperature of $30{ }^{\circ} \mathrm{C}$; water bath temperature of $50{ }^{\circ} \mathrm{C}$ and water bath time of $1 \mathrm{~h}$ following the application of ultrasound. The main phases present in the residue were $\mathrm{FeC}_{2} \mathrm{O}_{4} \cdot 2 \mathrm{H}_{2} \mathrm{O}$ (Fig. 11), and a purified solution containing $0.327 \mathrm{~g} / \mathrm{L} \mathrm{Ga}, 0.442 \mathrm{~g} / \mathrm{L} \mathrm{Ge}, 0.050 \mathrm{~g} / \mathrm{L} \mathrm{Fe}, 0.089 \mathrm{~g} / \mathrm{L}$ $\mathrm{Zn}, 0.014 \mathrm{~g} / \mathrm{L} \mathrm{Cu}$ and $0.015 \mathrm{~g} / \mathrm{L} \mathrm{Si}$.

\subsection{Separation of Ga and Ge from purified solution}

In order to recovery and enrich the Ga and Ge effectively, a solvent extraction method was carried out using a mixed extractant that comprised of $20 \%(\mathrm{v} / \mathrm{v}) \mathrm{N} 235,10 \%(\mathrm{v} / \mathrm{v})$ TBP and $70 \%(\mathrm{v} / \mathrm{v})$ sulfonated kerosene. The optimum conditions determined for the solvent extraction were: a contact time of $15 \mathrm{~min}$, temperature of $25^{\circ} \mathrm{C}$ and an O:A ratio of 1:4. Under these optimum conditions, $99.36 \%$ of the Ga and $99.89 \%$ of the Ge could be extracted and a loaded organic phase that contained $1.308 \mathrm{~g} / \mathrm{L} \mathrm{Ga}$ and $1.766 \mathrm{~g} / \mathrm{L} \mathrm{Ge}$ was obtained. The separation of $\mathrm{Ga}$ and Ge from the organic phase was conducted using sequential treatment steps with $\mathrm{H}_{2} \mathrm{SO}_{4}$ and $\mathrm{NaOH}$ solution.

Firstly, $98.91 \%$ of the $\mathrm{Ga}$ and $0.02 \%$ of the Ge in the loaded organic phase were stripped respectively by $\mathrm{H}_{2} \mathrm{SO}_{4}(2 \mathrm{~mol} / \mathrm{L})$ for $15 \mathrm{~min}$ at $30{ }^{\circ} \mathrm{C}$ with an A:O ratio of $1: 1$, and a stripping liquor containing $1.290 \mathrm{~g} / \mathrm{L} \mathrm{Ga}$ 
and $0.004 \mathrm{~g} / \mathrm{L} \mathrm{Ge}$ was obtained. After Ga stripping, 99.21\% of the Ge and $0.52 \%$ of the $\mathrm{Ga}$ in the loaded organic phase were then stripped using $\mathrm{NaOH}(4 \mathrm{~mol} / \mathrm{L})$ for $15 \mathrm{~min}$ at $40{ }^{\circ} \mathrm{C}$ with an $\mathrm{A}: \mathrm{O}$ ratio of $1: 1$ resulting in a stripping liquor that contained $0.006 \mathrm{~g} / \mathrm{L} \mathrm{Ga}$ and $1.751 \mathrm{~g} / \mathrm{L} \mathrm{Ge}$, respectively.

According to the results obtained in the experiments presented above, the proposed flow sheet for treatment of zinc refinery residues containing high silica and iron is shown in Fig.12.

\section{Conclusions}

On the basis of the comprehensive characterization of materials, in this paper a hydrometallurgical process for treating a $\mathrm{Ga}$ and $\mathrm{Ge}$ rich zinc refinery residue was investigated. It was found that $\mathrm{Ga}$ and $\mathrm{Ge}$ in the zinc refinery residue mainly exist as dissociative or combined oxides that correlate with the presence of iron and silica. Under leaching conditions that comprised of an $\mathrm{H}_{2} \mathrm{C}_{2} \mathrm{O}_{4}$ concentration of $110 \mathrm{~g} / \mathrm{L}, \mathrm{H}_{2} \mathrm{O}_{2}$ concentration of $0.12 \mathrm{~mol} / \mathrm{L}$, a leaching time of $30 \mathrm{~min}$, an $\mathrm{L} / \mathrm{S}$ ratio of 8 and a temperature of $40{ }^{\circ} \mathrm{C}, 99.32 \%$ of the $\mathrm{Ga}, 98.86 \%$ of the $\mathrm{Ge}$ and $30.25 \%$ of the $\mathrm{Fe}$ were leached out. In contrast, the leaching of $\mathrm{Zn}, \mathrm{Cu}$ and Si was only $0.30 \%, 0.82 \%$ and $0.43 \%$, respectively. Purification by the ultrasound - assisted iron powder replacement process allowed $98.31 \%$ of the iron to be removed in the form of $\mathrm{FeC}_{2} \mathrm{O}_{4} \cdot 2 \mathrm{H}_{2} \mathrm{O}$, whilst the concurrent losses of $\mathrm{Ga}$ and $\mathrm{Ge}$ were found to be $1.08 \%$ and $0.68 \%$, respectively. After purification, $99.36 \%$ of the $\mathrm{Ga}$ and $99.89 \%$ of the $\mathrm{Ge}$ were extracted by N235 : TBP : kerosene. Finally, $98.91 \%$ of the Ga and $99.21 \%$ of the Ge loaded in the organic phase were stripped into different solutions using sequential treatments of $2 \mathrm{~mol} / \mathrm{L} \mathrm{H}_{2} \mathrm{SO}_{4}$ and $4 \mathrm{~mol} / \mathrm{L}$ $\mathrm{NaOH}$. The resultant pregnant solutions obtained had concentrations of $1.290 \mathrm{~g} / \mathrm{L} \mathrm{Ga}\left(\mathrm{H}_{2} \mathrm{SO}_{4}\right)$ and $1.751 \mathrm{~g} / \mathrm{L} \mathrm{Ge}(\mathrm{NaOH})$. Pure gallium can be 
obtained by electrolysis after adjusting the alkalinity of the enriched gallium solution with $\mathrm{NaOH}$, whereas the germanium can be further recovered by chlorinated distillation process from the products that originate from neutralization precipitation of enriched germanium solution. In addition, the effective recovery of valuable metals ( $\mathrm{Zn}, \mathrm{Fe}$, $\mathrm{Cu}, \mathrm{Pb}$ ) from leaching residues can be realized by the combination of rotary kiln calcination and hydrometallurgical treatment processes. The results detailed in paper demonstrate that almost complete separation and recovery of gallium and germanium from the zinc refinery residue could be obtained using this technology.

\section{Acknowledgements}

This work was financially supported by the National Science Foundation of China (51574285).

\section{References}

Ambikadevi, V.R., Lalithambika, M., 2000. Effect of organic acids on ferric iron removal from iron-stained kaolinite. Appl. Clay Sci. 16, 133-145.

Arvin, E., Pedersen, L.F., 2015. Hydrogen peroxide decomposition kinetics in aquaculture water. Aquac. Eng. 64, 1-7.

Bodas, M.G., 1996. Hydrometallurgical treatment of zinc silicate ore from Thailand. Hydrometallurgy 40 (1-2), 37-49.

Chen, F., Wang, X.M., Liu, W.Z., Liang, B., Yue, H., Li, C., 2016. Selective extraction of nitric and acetic acids from etching waste acid using N235 and MIBK mixtures. Separation and Purification Technology169, 56-58.

Chenakin, S.P., Szukiewicz, R., Barbosa, R., Kruse, N., 2016. Surface analysis of transition metal oxalates: Damage aspects. Journal of Electron Spectroscopy and Related Phenomena 209, 66-77.

Demopoulos, G.P., Mihaylov, I.O., Pouskouleli, G., 1993. Synergistic extraction of 
iron(III) from sulphuric acid solutions with mixed kelex 100-alkyl phosphorus acid extractants, Solvent Extr. Ion Exch. 11 (1), 67-89.

Depuydt, B., Theuwis, A., Romandic, I., 2006. Germanium: From the first application of Czochralskicrystal growth to large diameter dislocation-free wafers. Materials Science in Semiconductor Processing 9, 437-443.

Dutrizac, J.E., Chen, T.T., Longton, R.J., 1996. The mineralogical deportment of germanium in the Clarksville electrolytic zinc plant of Savage Zinc Inc. Metallurgical and Materials Transaction B27 (4), 567-576.

Efremov, V.A., Potolokov, V.N., Nikolashin, S.V., Fedorov, V.A., 2002. Chemical equilibria in hydrolysis of germanium tetrachloride and arsenic trichloride. Inorganic Materials 38 (3), 847-853.

Fang, D.W., Shan, W.J., Yan, Q., Li, D., Xia, L.X., Zang, S.D., 2014. Extraction of rhenium from sulphuric acid solution with used amine N235, Fluid Phase Equilibria $383,1-4$.

Fujiwara, M., Hirao, T., Kawada, M., Shibai, H., Matsuura, S., Kaneda, H., Patrashin, M., Nakagawa, T., 2003. Development of a gallium-doped germanium far-infrared photoconductor direct hybrid two-dimensional array. Applied Optics 42 (12), 21662173.

Gong, B.Z., Wang, X.P., Guo, F.J., 2006. Determination of residues oxalate in submicron graphite cake by using potassium hypermanganate volume method. Shandong Chemical Industry 35, 31-32. (In Chinese)

Harbuck, D.D., 1993. Increasing germanium extraction from hydrometallurgical zinc residues. Minerals and Metallurgical Processing 10 (1), 1-4.

Harbuck, D.D., Morrison, J.W., Davidson, C.F., 1989. Optimization of gallium and germanium extraction from hydrometallurgical zinc residue. Light Metals (5), 984989.

He, G.X., Zhao, Z.W., Wang, X.B., Li, J.T., Chen, X.Y., He, L.H., Liu, X.H., 2014. Leaching kinetics of scheelite in hydrochloric acid solution containing hydrogen peroxide as complexing agent. Hydrometallurgy 144-145 (4), 140-147.

Hua, Y., Lin, Z., Yan, Z., 2002. Application of microwave irradiation to quick leaching of zinc silicate ore. Minerals Engineering 15 (6), 451-456.

Kang, J., Sohn, J., Chang, H., Senanayake, G., Shin, S.M., 2010. Preparation of cobalt oxide from concentrated cathode material of spent lithium ion batteries by hydrometallurgical method. Adv. Powder Technol. 21, 175-179. 
Kul, M., Topkaya, Y., 2008. Recovery of germanium and other valuable metals from zinc plant residues. Hydrometallurgy 92 (3-4), 87-94.

Lee, S.O., Tran, T., Jung, B.H., Kim, S.J., Kim, M.J., 2007. Dissolution of iron oxide using oxalic acid. Hydrometallurgy 87, 91-99.

Lee, H.Y., Kim, S.G., Oh, J.K., 1994. Process for recovery of gallium and germanium from zinc residues. Transactions of the Institution of Mining and Metallurgy103 (4), 76-79.

Liang, D.Q., Wang, J.K., Wang, Y.H., 2009. Difference in dissolution between germanium and zinc during the oxidative pressure leaching of sphalerite. Hydrometallurgy 95 (1), 5-7.

Liu, F.P., Liu, Z.H., Li, Y.H., Liu, Z.Y., Li, Q.H., 2016a. Sulfuric leaching process of zinc powder replacement residue containing gallium and germanium. The Chinese Journal of Nonferrous Metal 26 (4), 908-916. (In Chinese)

Liu, F.P., Liu, Z.H., Li, Y.H., Liu, Z.Y., Li, Q.H., Zeng, L., 2016b. Extraction of gallium and germanium from zinc refinery residues by pressure acid leaching. Hydrometallurgy 164, 313-320.

Liu, J., Qiu, Z.F., Yang, J., Cao, L. M., Zhang, W., 2016c. Recovery of Mo and Ni from spent acrylonitrile catalysts using an oxidation leaching-chemical precipitation technique. Hydrometallurgy 164, 64-70.

Liu, Y.Q., 1992. Chemical phase analysis of ores and industrial products. Metallurgical Industry Press, Beijing, 162-168. (In Chinese)

Mishra, R.K., Rout, P.C., Sarangi, K., Nathsarma, K.C., 2010. A comparative study on extraction of Fe (III) from chloride leach liquor using TBP, Cyanex 921 and Cyanex 923. Hydrometallurgy 104, 298-303.

Ni, L., Wang, L., Shao, B., Wang, Y.J., Zhang, W.L., Jiang, Y., 2011. Synthesis of flower-like zinc oxalate microspheres in ether-water bilayer refluxing systems and their conversion to zinc oxide microspheres. J. Mater. Sci. Technol. 27 (6), 563-569. Nishihama, S., Hirai, T., Komasawa, I., 1999. Separation and recovery of gallium and indium from simulated zinc refinery residue by liquid-liquid extraction. Industrial and Engineering Chemistry Research 38 (3), 1032-1039.

Nusen, S., Zhu, Z.W., Chairuangsri, T., Cheng, C.Y., 2015. Recovery of germanium from synthetic leach solution of zinc refinery residues by synergistic solvent extraction using LIX 63 and Lonquest 801. Hydrometallurgy 151, 122-132. 
Pokrovski, G.S., Schott, J., 1998. Experimental study of the complexation of silicon and germanium with aqueous organic species: Implications for germanium and silicon transport and $\mathrm{Ge} / \mathrm{Si}$ ratio in natural waters. Geochimica et Cosmochimica Acta, 62 (21-22), 3413-3428.

Principe, F., Demopoulos, G.P., 2004. Comparative study of iron(III) separation from zinc sulphate-sulphuric acid solutions using the organophosphorus extractants, OPAP and D2EHPA, Part I: Extraction. Hydrometallurgy 74, 93-102.

Principe, F., Demopoulos, G.P., 2005. Comparative study of iron(III) separation from zinc sulphate-sulphuric acid solutions using the organophosphorus extractants, OPAP and D2EHPA, Part II: Stripping. Hydrometallurgy 79, 97-109.

Schimmel, R.C., Faber, A.J., De, W.H., Beerkens, R.G.C., Khoe, G.D., 2001. Development of germanium gallium sulphide glass fibres for the $1.31 \mu \mathrm{m}$ praseodymium-doped fibre amplifier. Journal of Non-crystalline Solids 284(1), 188192.

Sun, L., Qiu, K.Q., 2012. Organic oxalate as leachant and precipitant for the recovery of valuable metals from spent lithium-ion batteries. Waste Management 32(8), 15751582 .

Sun, X.X., Sun, Y.Z., Yu, J.G., 2016. Removal of ferric ions from aluminum solutions by solvent extraction, part I: Iron removal. Separation and purification Technology 159, 18-22.

Szymczycha-Madeja, A., 2011. Kinetics of Mo, Ni, V and Al leaching from a spent hydrodesulphurization catalyst in a solution containing oxalic acid and hydrogen peroxide. J. Hazard. Mater. 186, 2157-2161.

Taxiarchou, M., Panias, D., Douni, I., Paspaliaris, I., Kontopoulos, A., 1997. Removal of iron from silica sand by leaching with oxalic acid. Hydrometallurgy 46, 215-227. Torma, A.E., 1991. Method of extracting gallium and germanium. Mineral Processing and Extractive Metallurgy Review 7(3), 235-258.

Tuncuk, A., Akcil, A., 2016. Iron removal in production of purified quartz by a hydrometallurgical process. International Journal of Mineral Processing 153, 44-50.

Tyszczuk, K., Korolczuk, M., Grabarczyk, M., 2007. Application of gallium film electrode for elimination of copper interference in anodic stripping voltammetry of zinc. Talanta 71 (5), 2098-2101.

Veglio, F., Passariello, B., Abbruzzese, C., 1999. Iron removal process for high-purity 
silica sands production by oxalic acid leaching. Industrial and Engineering Chemistry Research 38, 4443-4448.

Yang, X.L., Zhang, J.W., Fang, X.H., 2015. Extraction kinetics of niobium by tertiary amine N235 using Lewis cell. Hydrometallurgy 151, 56-61.

Yu, L., Fu, B., 2004. Handbook of Nonferrous Metallurgical Analysis. Metallurgical Industry Press, Beijing, 226-229, 230-232. (in Chinese)

Zhang, L.B., Guo, W.Q., Peng, J.H., Li, J., Lin G., Yu, X., 2016a. Comparison of ultrasonic-assisted and regular leaching of germanium from by-product of zinc metallurgy. Ultrasonics Sonochemistry 31, 143-149.

Zhang, W. J., Zhao, Z. W., Huang, S. B., Chen, X. Y., Hu, K.L., 2016b. Recovery and separation of $\mathrm{W}$ and Mo from high-molybdenum synthetic scheelite in $\mathrm{HCl}$ solutions containing $\mathrm{H}_{2} \mathrm{O}_{2}$. Hydrometallurgy 155, 1-5. 
Table 1. Contents of the major component of interest in the zinc refinery residue. (wt.\%).

\begin{tabular}{cccccccc}
\hline $\mathrm{Zn}$ & $\mathrm{Cu}$ & $\mathrm{Fe}$ & $\mathrm{Fe}(\mathrm{II})$ & $\mathrm{SiO}_{2}$ & $\mathrm{Ga}$ & $\mathrm{Ge}$ & $\mathrm{Pb}$ \\
\hline 24.45 & 5.55 & 7.88 & 3.74 & 9.14 & 0.266 & 0.362 & 0.46 \\
\hline
\end{tabular}

Table 2. Particle size distribution of the zinc refinery residue by wet screen analysis.

\begin{tabular}{cccccc}
\hline $\begin{array}{c}\text { Particle } \\
\text { size } / \mu \mathrm{m}\end{array}$ & $<45$ & $45-60$ & $60-93$ & $93-150$ & $>150$ \\
\hline wt. $\%$ & 75.81 & 4.81 & 4.66 & 10.83 & 3.89 \\
\hline
\end{tabular}

Table 3. Main parameters investigated in the experiments.

\begin{tabular}{|c|c|}
\hline Experiment & Investigated parameters \\
\hline $\begin{array}{l}\text { Oxalic acid } \\
\text { leaching stage }\end{array}$ & $\begin{array}{l}\mathrm{L} / \mathrm{S}(\mathrm{mL} / \mathrm{g}): 4-12 ; \text { Temperature }\left({ }^{\circ} \mathrm{C}\right): 30-60 ; \mathrm{H}_{2} \mathrm{C}_{2} \mathrm{O}_{4}(\mathrm{~g} / \mathrm{L}): 40-130 ; \\
\mathrm{H}_{2} \mathrm{O}_{2}(\mathrm{~mol} / \mathrm{L}): 0-0.2 ; \text { Reaction time (min): } 10-60\end{array}$ \\
\hline Iron removal & $\begin{array}{l}\mathrm{Fe} / \mathrm{Fe}(\mathrm{III}) \text { mole ratio: } 2-8 \text {; Ultrasound }(200 \mathrm{~W}) \text { time }(\mathrm{min}): 0-15 \text {; } \\
\text { Water bath temperature }\left({ }^{\circ} \mathrm{C}\right): 30-70 \text {; Water bath time }(\mathrm{h}): 0.5-2\end{array}$ \\
\hline Solvent extraction & $\begin{array}{l}\text { Reaction time (min): 5-20; Temperature }\left({ }^{\circ} \mathrm{C}\right): 15-35 ; \mathrm{N} 235(\mathrm{v} / \mathrm{v}) \text { : } \\
5-10 \% \text {; Organic/aqueous phase ratio(v/v)(O:A): 2:1-1:6 }\end{array}$ \\
\hline Stripping & $\begin{array}{l}\text { Reaction time }(\mathrm{min}): 10-30 ; \text { Temperature }\left({ }^{\circ} \mathrm{C}\right): 25-50 ; \mathrm{H}_{2} \mathrm{SO}_{4} \\
(\mathrm{~mol} / \mathrm{L}): 1-4 ; \mathrm{NaOH}(\mathrm{mol} / \mathrm{L}): 2-6 ; \mathrm{A}: \mathrm{O}: 1: 4-2: 1\end{array}$ \\
\hline
\end{tabular}

Table 4. EPMA results of the analysis points of the zinc refinery residues displayed in Figure 2 (wt.\%).

\begin{tabular}{ccccccccccc}
\hline Spot & $\mathrm{O}$ & $\mathrm{Ge}$ & $\mathrm{S}$ & $\mathrm{Ga}$ & $\mathrm{Zn}$ & $\mathrm{Fe}$ & $\mathrm{Cu}$ & $\mathrm{Si}$ & $\mathrm{Pb}$ & $\mathrm{Ca}$ \\
\hline 1 & 39.703 & 0.073 & 10.587 & 0.041 & 22.308 & 1.702 & 3.119 & 2.682 & 0.256 & 0.060 \\
2 & 39.922 & 0.838 & 2.708 & 0.431 & 21.016 & 5.868 & 5.564 & 6.476 & 1.28 & $\mathrm{ND}$ \\
3 & 41.632 & 0.813 & 2.590 & 0.312 & 12.867 & 5.947 & 2.728 & 12.384 & 0.283 & 5.450 \\
4 & 41.476 & 0.407 & 4.259 & 0.237 & 24.283 & 5.475 & 5.523 & 2.253 & 0.319 & 0.467 \\
5 & 55.199 & 0.506 & 3.204 & 0.482 & 14.014 & 4.526 & 5.685 & 6.164 & 0.723 & 10.45 \\
6 & 27.399 & 0.104 & 0.492 & 0.159 & 16.792 & 41.075 & 1.229 & 0.483 & 0.069 & $\mathrm{ND}$ \\
7 & 46.982 & 0.046 & 10.934 & 0.500 & 22.665 & 2.547 & 3.701 & 1.245 & 0.472 & 14.050 \\
8 & 40.975 & 0.725 & 1.348 & 0.286 & 13.545 & 5.245 & 1.756 & 14.548 & 0.210 & 3.145 \\
9 & 46.145 & 0.564 & 6.145 & 0.524 & 24.145 & 2.156 & 5.482 & 13.245 & 0.275 & 0.896 \\
10 & 47.176 & 0.542 & 4.235 & 0.422 & 23.172 & 3.458 & 4.467 & 9.789 & 0.315 & 3.456 \\
11 & 28.455 & 0.115 & 0.385 & 0.162 & 17.042 & 42.025 & 0.768 & 0.445 & 0.104 & 0.135 \\
12 & 50.324 & 0.465 & 4.865 & 0.452 & 16.415 & 2.576 & 5.425 & 6.784 & 0.113 & 2.745 \\
13 & 39.017 & 0.135 & 0.296 & 0.344 & 20.319 & 37.530 & 0.703 & 0.549 & 0.066 & 1.087 \\
14 & 42.325 & 0.856 & 3.096 & 0.295 & 12.067 & 5.846 & 2.708 & 15.384 & 0.243 & 2.645 \\
15 & 46.785 & 0.607 & 4.651 & 0.197 & 25.086 & 5.145 & 5.420 & 11.253 & 0.319 & 0.467 \\
\hline ND - not detected at a minimum detection limit of 300 ppm. \\
\hline
\end{tabular}


Table 5. Phase composition of gallium and germanium in the zinc refinery residue.

\begin{tabular}{ccc|ccc}
\hline Germanium phases & wt.\% & Distribution/\% & Gallium phases & wt.\% & Distribution/\% \\
\hline $\mathrm{MeO} \cdot \mathrm{GeO}_{2}$ & 0.222 & 61.32 & $\mathrm{MeO} \cdot \mathrm{Ga}_{2} \mathrm{O}_{3}$ & 0.076 & 28.58 \\
$\mathrm{GeO}+\mathrm{GeO}_{2}$ & 0.081 & 22.38 & $\mathrm{Ga}_{2} \mathrm{O}_{3}$ & 0.187 & 70.30 \\
$\mathrm{Ge}+\mathrm{GeS}_{2}+\mathrm{GeS}$ & 0.059 & 16.30 & $\mathrm{Ga}+\mathrm{Ga}_{2} \mathrm{~S}_{3}$ & 0.003 & 1.12 \\
\hline Total & 0.362 & 100 & Total & 0.266 & 100 \\
\hline
\end{tabular}

Table 6. The main reaction and corresponding equilibrium constants in oxalate leaching stage $(298.15 \mathrm{~K})$.

\begin{tabular}{|c|c|c|c|}
\hline No. & Reaction & $\log \mathrm{K}$ & References \\
\hline$(5)$ & $\mathrm{Ga}_{2} \mathrm{O}_{3}+6 \mathrm{HC}_{2} \mathrm{O}_{4}^{-}=2 \mathrm{Ga}\left(\mathrm{C}_{2} \mathrm{O}_{4}\right)_{3}^{3-}+3 \mathrm{H}_{2} \mathrm{O}$ & 9.12 & $\begin{array}{c}\text { Weast (1976) } \\
\text { HSC } 7.0\end{array}$ \\
\hline$(6)$ & $\mathrm{GeO}_{2}+2 \mathrm{HC}_{2} \mathrm{O}_{4}^{-}=\mathrm{Ge}(\mathrm{OH})_{2}\left(\mathrm{C}_{2} \mathrm{O}_{4}\right)_{2}^{2-}$ & 2.95 & $\begin{array}{c}\text { Everest(1955) } \\
\text { Pokrovski(1998) }\end{array}$ \\
\hline$(7)$ & $\mathrm{SiO}_{2}+\mathrm{HC}_{2} \mathrm{O}_{4}^{-}+\mathrm{H}^{+}=\mathrm{Si}(\mathrm{OH})_{2} \mathrm{C}_{2} \mathrm{O}_{4}$ & -16.64 & $\begin{array}{c}\text { Bennett(1991) } \\
\text { Pokrovski(1998) }\end{array}$ \\
\hline$(8)$ & $\mathrm{Fe}^{2+}+\mathrm{C}_{2} \mathrm{O}_{4}^{2-}+2 \mathrm{H}_{2} \mathrm{O}=\mathrm{FeC}_{2} \mathrm{O}_{4} \cdot 2 \mathrm{H}_{2} \mathrm{O}$ & 6.47 & Weast (1976) \\
\hline (9) & $\mathrm{Fe}_{2} \mathrm{O}_{3}+2 \mathrm{HC}_{2} \mathrm{O}_{4}^{-}+4 \mathrm{H}^{+}=2 \mathrm{Fe}\left(\mathrm{C}_{2} \mathrm{O}_{4}\right)^{+}+3 \mathrm{H}_{2} \mathrm{O}$ & 10.50 & Weast (1976) \\
\hline$(10)$ & $\mathrm{ZnFe}_{2} \mathrm{O}_{4}+3 \mathrm{HC}_{2} \mathrm{O}_{4}^{-}+5 \mathrm{H}^{+}=\mathrm{ZnC}_{2} \mathrm{O}_{4} \cdot 2 \mathrm{H}_{2} \mathrm{O}+2 \mathrm{Fe}\left(\mathrm{C}_{2} \mathrm{O}_{4}\right)^{+}+3 \mathrm{H}_{2} \mathrm{O}$ & 14.30 & Weast (1976) \\
\hline$(11)$ & $\mathrm{ZnO}+\mathrm{HC}_{2} \mathrm{O}_{4}^{-}+\mathrm{H}^{+}+\mathrm{H}_{2} \mathrm{O}=\mathrm{ZnC}_{2} \mathrm{O}_{4} \cdot 2 \mathrm{H}_{2} \mathrm{O}$ & 15.70 & Weast (1976) \\
\hline (12) & $\mathrm{CuO}+\mathrm{HC}_{2} \mathrm{O}_{4}^{-}+\mathrm{H}^{+}=\mathrm{CuC}_{2} \mathrm{O}_{4}+\mathrm{H}_{2} \mathrm{O}$ & 8.89 & Weast (1976) \\
\hline
\end{tabular}

Table 7. Gibbs free energy change of oxidation reaction involved with $\mathrm{H}_{2} \mathrm{O}_{2}$.

\begin{tabular}{cc}
\hline Equation No. & The values of $\Delta \mathrm{G}^{0}$ for the reactions $(313.15 \mathrm{~K}),(\mathrm{kJ} / \mathrm{mol})$ \\
\hline$(13)$ & -2228.870 \\
$(14)$ & -725.628 \\
$(15)$ & -1037.950 \\
$(16)$ & -3237.767 \\
$(17)$ & -653.126 \\
\hline
\end{tabular}

The values of $\Delta G^{0}$ were calculated using HSC Chemistry® 7.0 software.

Table 8. Contents of the major component of interest in the leaching residue (wt.\%).

\begin{tabular}{ccccccc}
\hline $\mathrm{Zn}$ & $\mathrm{Cu}$ & $\mathrm{Fe}$ & $\mathrm{SiO}_{2}$ & $\mathrm{Ga}$ & $\mathrm{Ge}$ & $\mathrm{Pb}$ \\
\hline 19.37 & 4.62 & 4.14 & 16.14 & 0.005 & 0.012 & 0.30 \\
\hline $\mathrm{Ca}$ & $\mathrm{Co}$ & $\mathrm{Ni}$ & $\mathrm{Al}$ & $\mathrm{As}$ & $\mathrm{Sn}$ & $\mathrm{S}$ \\
\hline 0.62 & 0.16 & 0.04 & 0.48 & 0.11 & 0.30 & 1.46 \\
\hline
\end{tabular}


Table 9. Effect of ultrasound time, $\mathrm{Fe} / \mathrm{Fe}(\mathrm{III})$ molar ratio, reaction temperature and reaction time on iron removal.

\begin{tabular}{|c|c|c|c|c|}
\hline Factors & & $\mathrm{Fe}(\%)$ & $\mathrm{Ge}(\%)$ & $\mathrm{Ga}(\%)$ \\
\hline $\mathrm{Fe} / \mathrm{Fe}(\mathrm{III})$ molar ratio & 2 & 78.69 & 0.59 & 0.54 \\
\hline \multirow[t]{3}{*}{ (Ultrasound time: $10 \mathrm{~min} ; 50^{\circ} \mathrm{C} ; 1 \mathrm{~h}$ ) } & 4 & 90.30 & 0.91 & 0.62 \\
\hline & 6 & 98.31 & 1.08 & 0.68 \\
\hline & 8 & 99.01 & 2.55 & 1.58 \\
\hline Ultrasound time (min) & $0 \min$ & 50.32 & 0.55 & 0.52 \\
\hline \multirow[t]{3}{*}{$\left(\mathrm{Fe} / \mathrm{Fe}(\mathrm{III}): 6 ; 50^{\circ} \mathrm{C} ; 1 \mathrm{~h}\right)$} & $5 \mathrm{~min}$ & 88.30 & 0.61 & 0.54 \\
\hline & $10 \min$ & 98.31 & 1.08 & 0.68 \\
\hline & $15 \mathrm{~min}$ & 98.56 & 1.10 & 0.72 \\
\hline Water bath temperature $\left({ }^{\circ} \mathrm{C}\right)$ & $30^{\circ} \mathrm{C}$ & 90.85 & 0.56 & 0.31 \\
\hline \multirow[t]{2}{*}{ (Ultrasound time:10 min; $\mathrm{Fe} / \mathrm{Fe}(\mathrm{III}): 6 ; 1 \mathrm{~h}$ ) } & $50{ }^{\circ} \mathrm{C}$ & 98.31 & 1.08 & 0.68 \\
\hline & $70^{\circ} \mathrm{C}$ & 98.71 & 2.17 & 1.75 \\
\hline Water bath time (h) & $0.5 \mathrm{~h}$ & 92.75 & 0.68 & 0.44 \\
\hline \multirow[t]{2}{*}{ (Ultrasound time: $10 \mathrm{~min} ; \mathrm{Fe} / \mathrm{Fe}(\mathrm{III}): 6 ; 50^{\circ} \mathrm{C}$ ) } & $1 \mathrm{~h}$ & 98.31 & 1.08 & 0.68 \\
\hline & $1.5 \mathrm{~h}$ & 98.90 & 1.24 & 1.38 \\
\hline
\end{tabular}




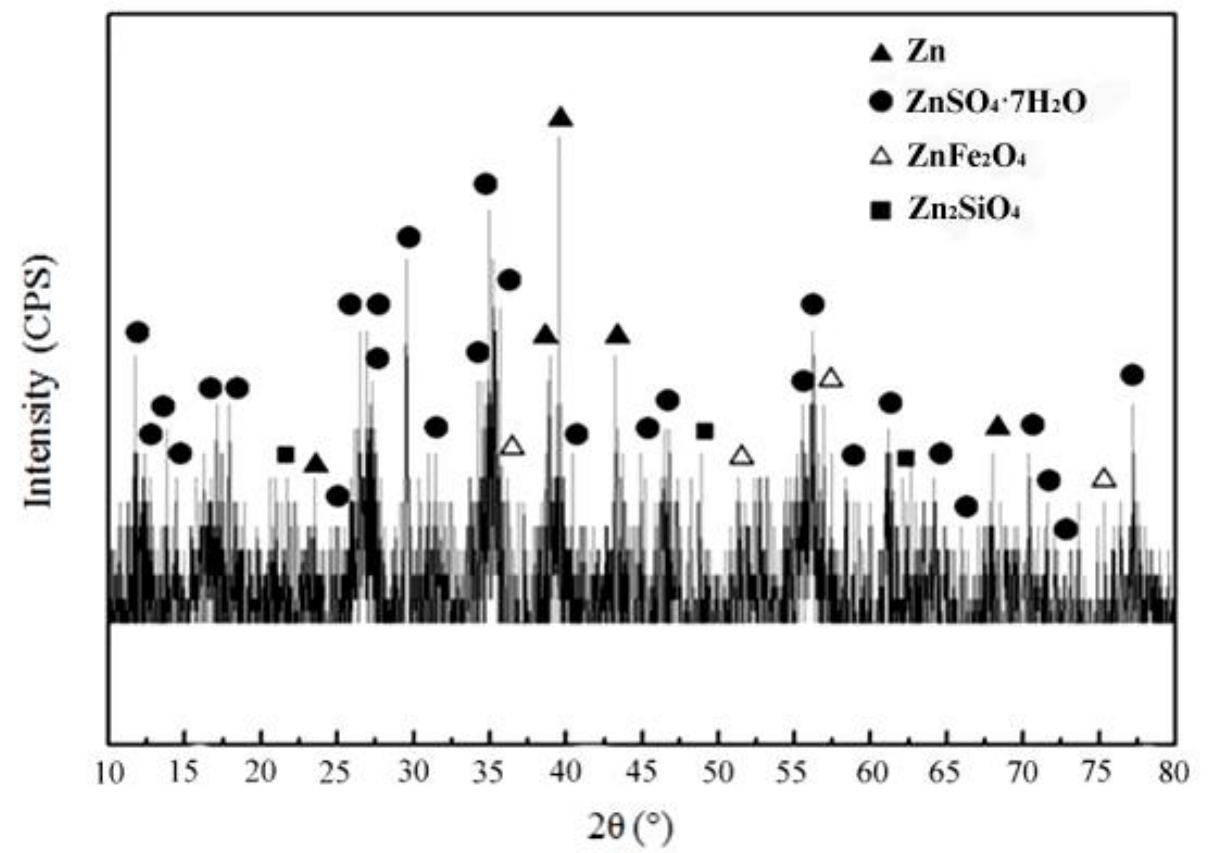

Fig. 1. X-ray diffraction pattern of the zinc refinery residue.

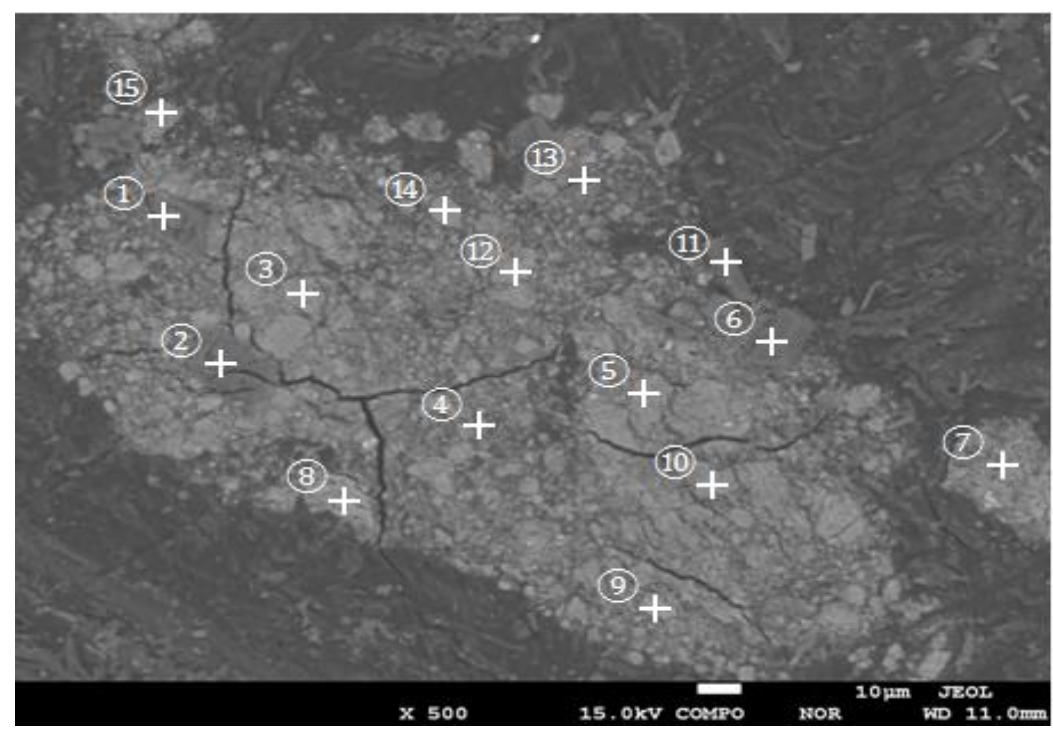

Fig. 2. Backscattered electron image of the zinc refinery residue. 


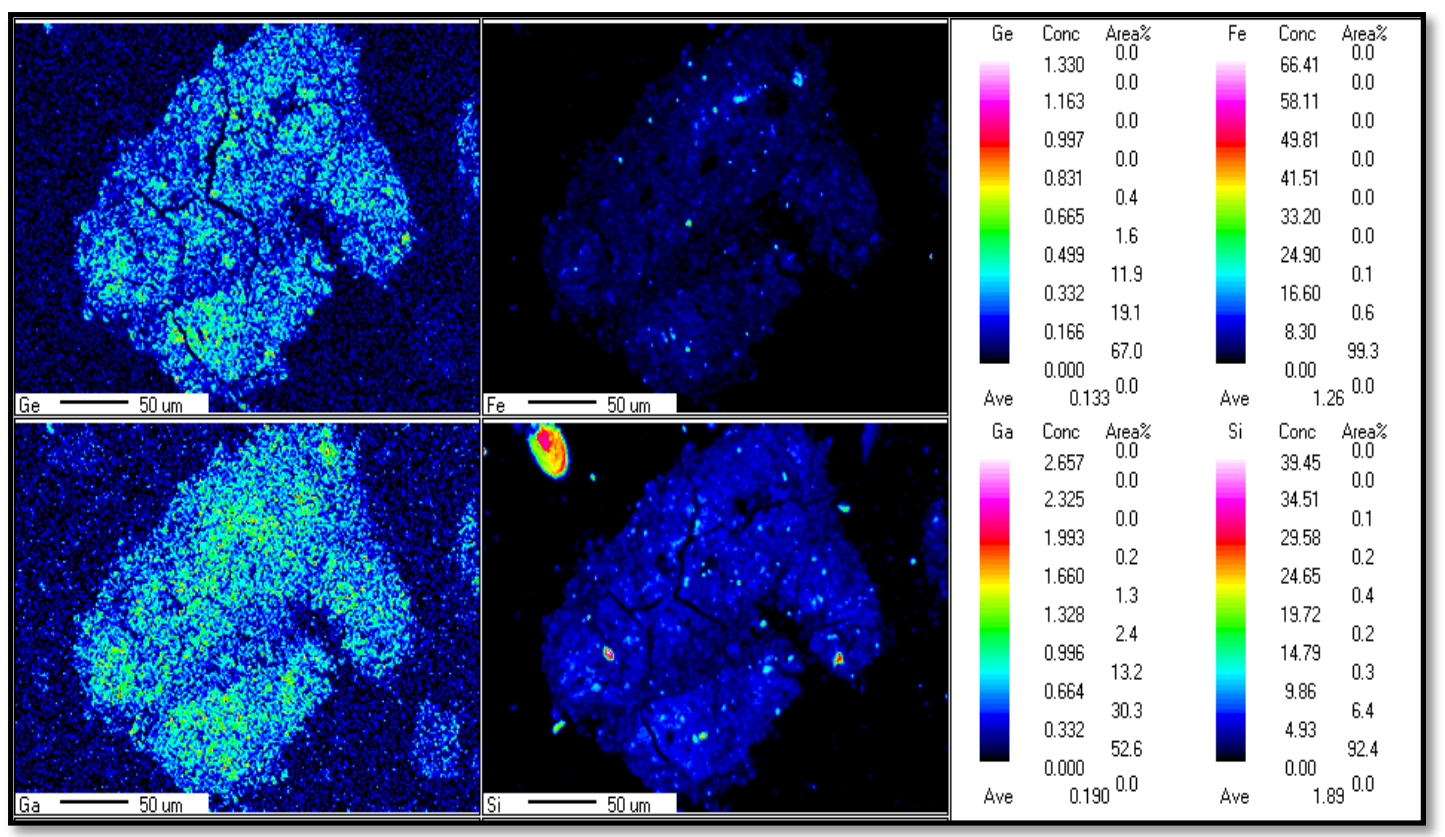

Fig. 3. Distribution maps of the $\mathrm{Ge}, \mathrm{Ga}, \mathrm{Fe}$ and $\mathrm{Si}$ in the zinc refinery residue.

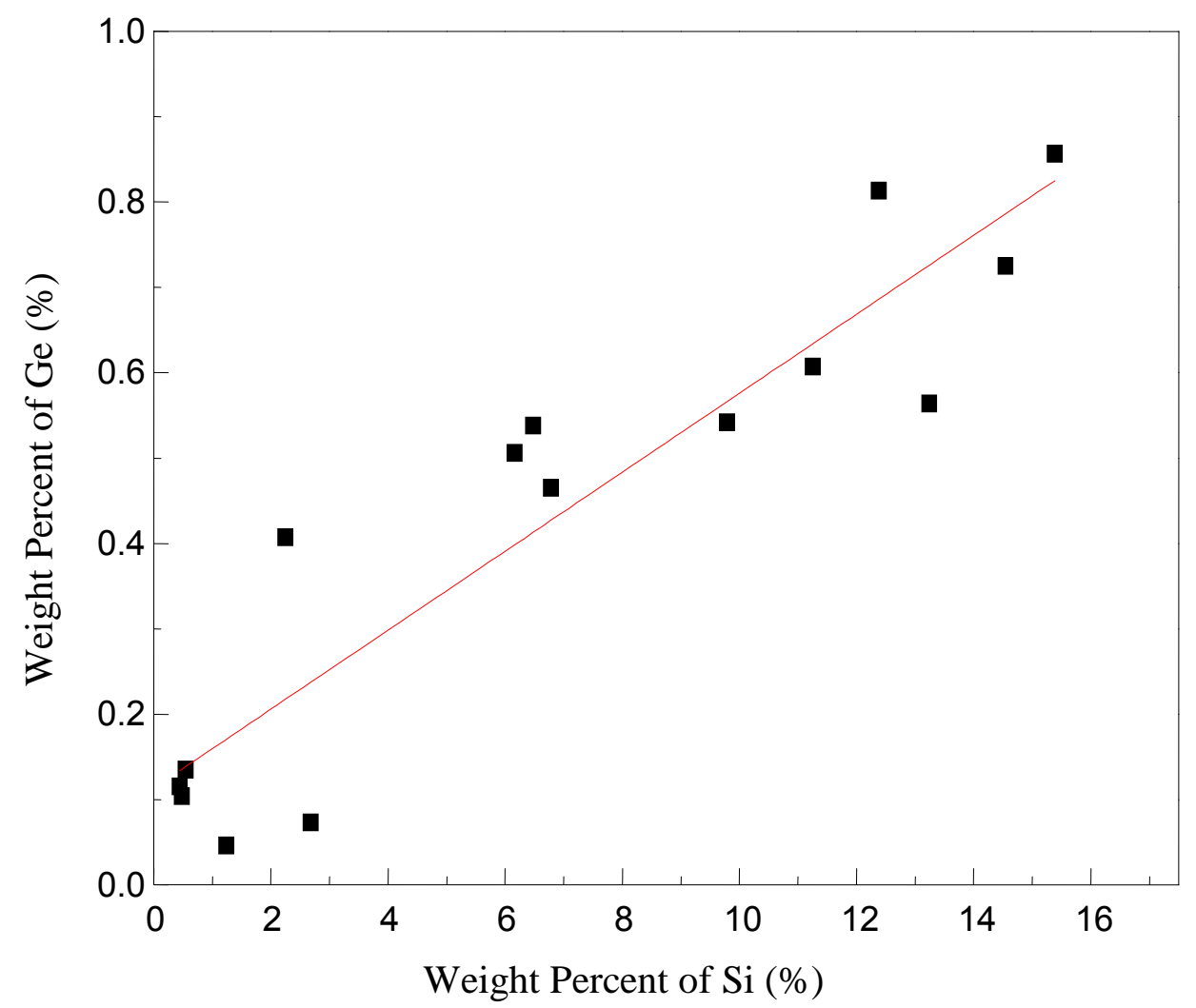

Fig. 4. The correlation of Si content and the amount of Ge present in the zinc refinery residue based on EPMA analysis in Table 4. 


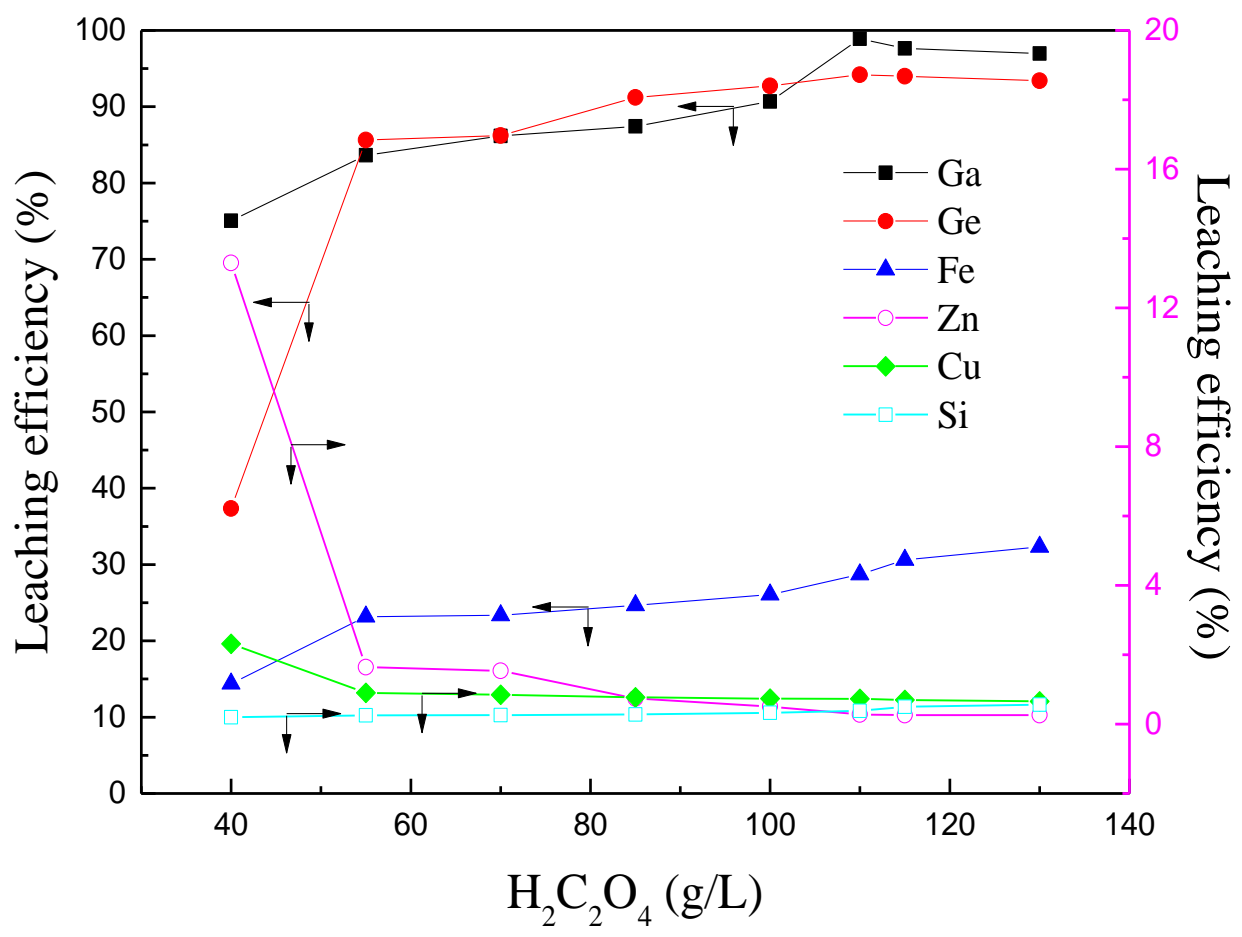

Fig. 5. Effect of oxalic acid concentration on the recovery of $\mathrm{Ga}, \mathrm{Ge}, \mathrm{Fe}, \mathrm{Cu}, \mathrm{Zn}$ and $\mathrm{Si}$ to the leach solution during zinc refinery residue leaching $\left(\mathrm{T}=40{ }^{\circ} \mathrm{C} ; \mathrm{L} / \mathrm{S}=8 ; \mathrm{t}=30 \mathrm{~min} ;\left[\mathrm{H}_{2} \mathrm{O}_{2}\right]=\right.$ $0.08 \mathrm{~mol} / \mathrm{L})$.

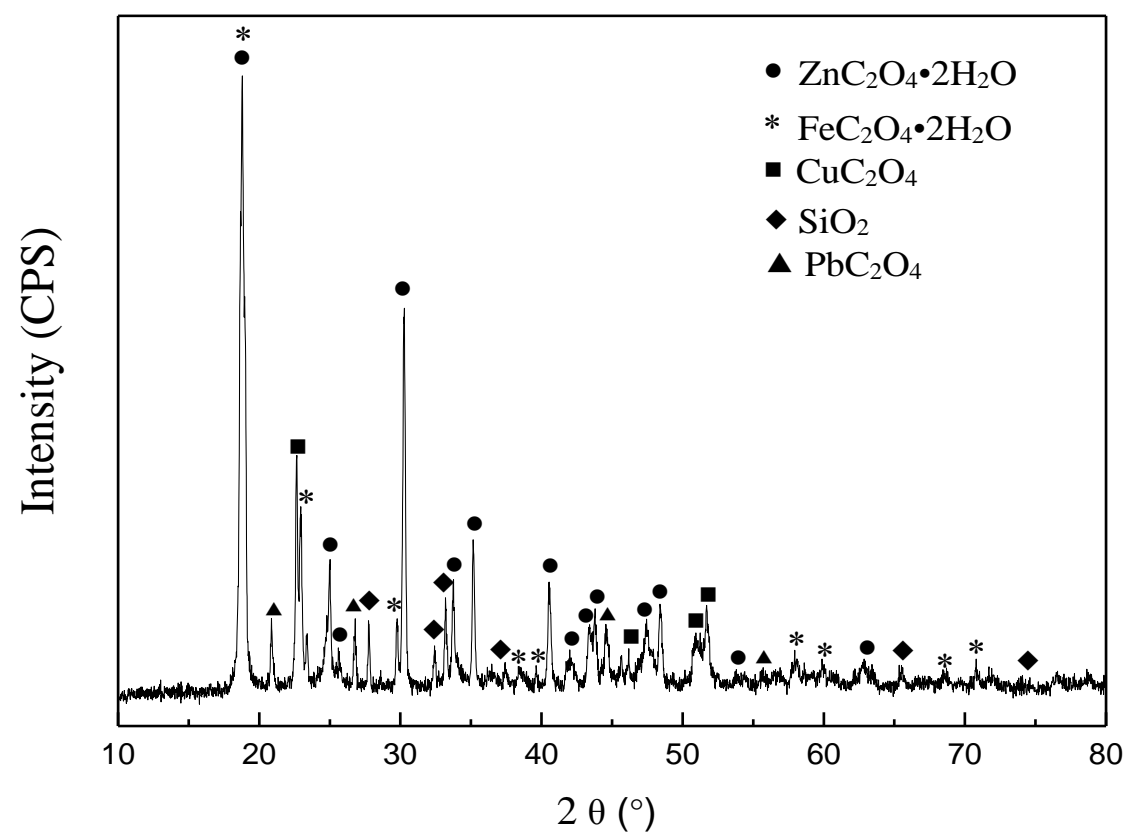

Fig. 6. $\mathrm{X}$-ray diffraction pattern of the leaching residue after oxalic acid leaching of zinc refinery residue $\left(\left[\mathrm{H}_{2} \mathrm{C}_{2} \mathrm{O}_{4}\right]=110 \mathrm{~g} / \mathrm{L} ; \mathrm{T}=40{ }^{\circ} \mathrm{C} ; \mathrm{L} / \mathrm{S}=8 ; \mathrm{t}=30 \mathrm{~min} ;\left[\mathrm{H}_{2} \mathrm{O}_{2}\right]=0.08 \mathrm{~mol} / \mathrm{L}\right)$. 


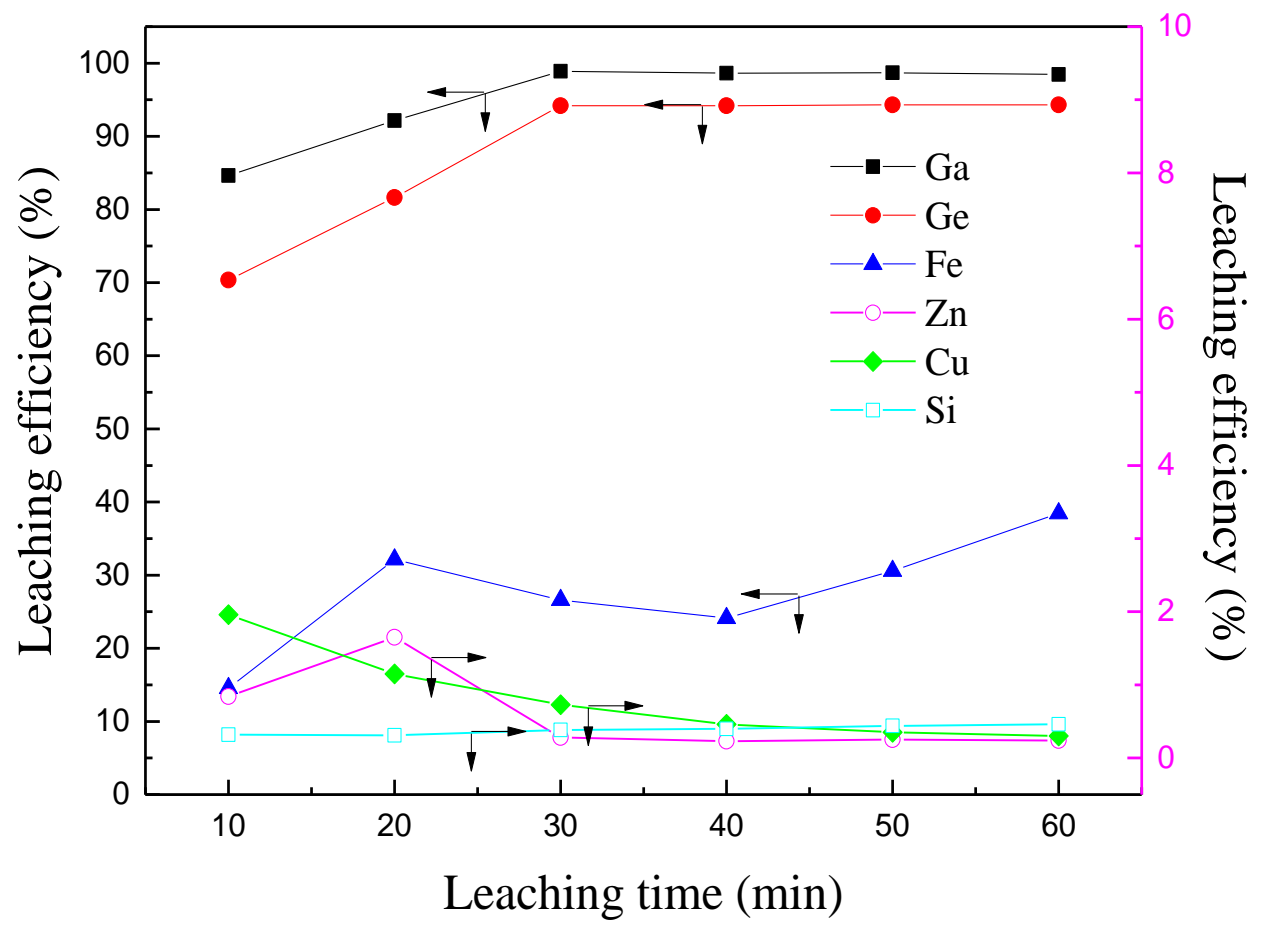

Fig. 7. Effect of leaching time on the recovery of $\mathrm{Ga}, \mathrm{Ge}, \mathrm{Fe}, \mathrm{Cu}, \mathrm{Zn}$ and $\mathrm{Si}$ to the leach solution during zinc refinery residue leaching $\left(\left[\mathrm{H}_{2} \mathrm{C}_{2} \mathrm{O}_{4}=110 \mathrm{~g} / \mathrm{L} ; \mathrm{L} / \mathrm{S}=8 ; \mathrm{T}=40{ }^{\circ} \mathrm{C} ;\left[\mathrm{H}_{2} \mathrm{O}_{2}\right]=0.08\right.\right.$ $\mathrm{mol} / \mathrm{L})$.

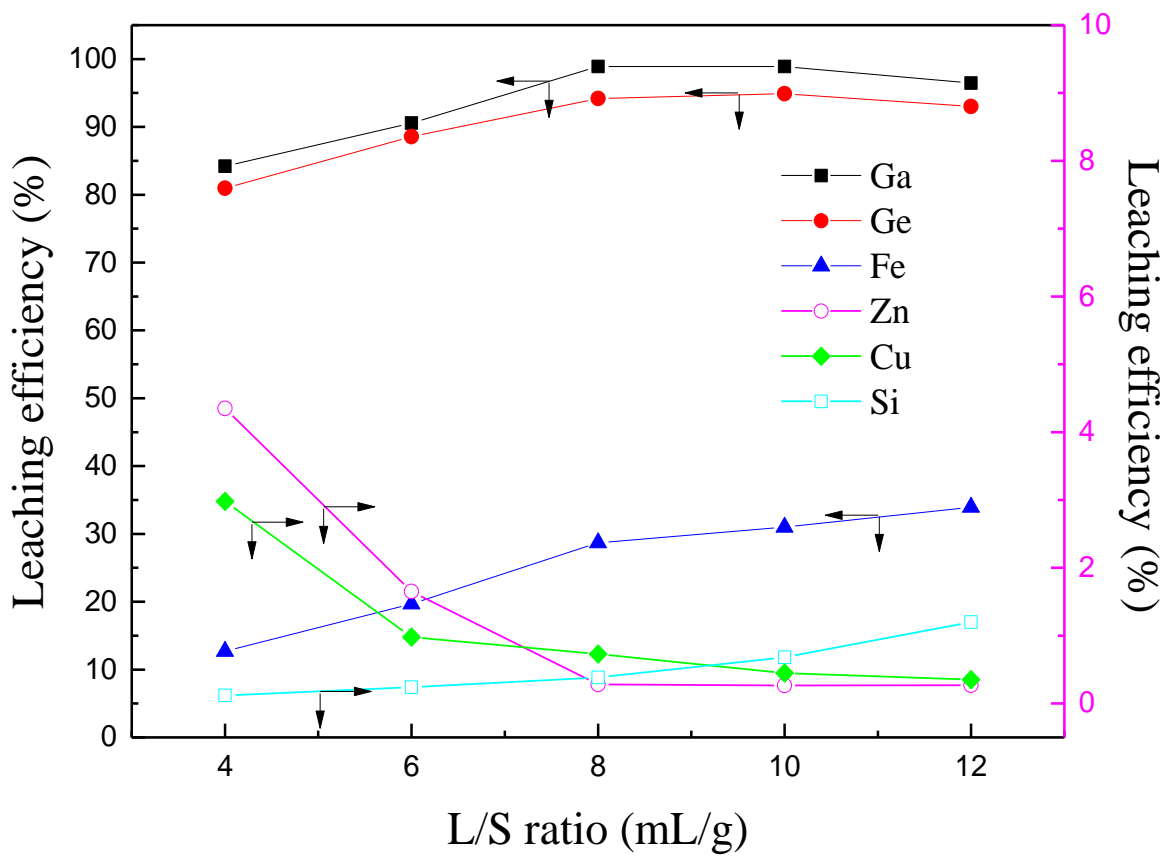

Fig. 8. Effect of $\mathrm{L} / \mathrm{S}$ ratio on the recovery of $\mathrm{Ga}, \mathrm{Ge}, \mathrm{Fe}, \mathrm{Cu}, \mathrm{Zn}$ and $\mathrm{Si}$ to the leach solution during zinc refinery residue leaching $\left(\left[\mathrm{H}_{2} \mathrm{C}_{2} \mathrm{O}_{4}\right]=110 \mathrm{~g} / \mathrm{L} ; \mathrm{T}=40^{\circ} \mathrm{C} ; \mathrm{t}=30 \mathrm{~min} ;\left[\mathrm{H}_{2} \mathrm{O}_{2}\right]=0.08\right.$ $\mathrm{mol} / \mathrm{L})$. 


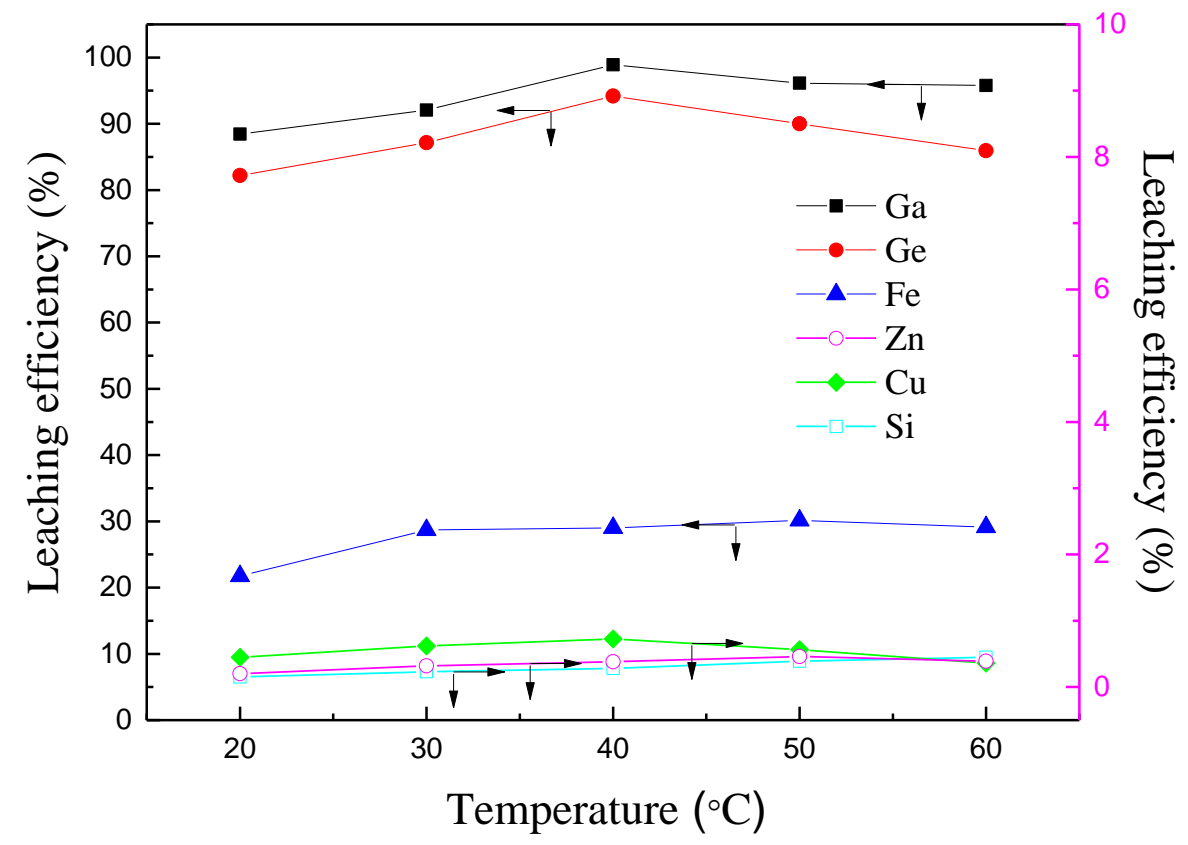

Fig. 9. Effect of temperature on the recovery of $\mathrm{Ga}, \mathrm{Ge}, \mathrm{Fe}, \mathrm{Cu}, \mathrm{Zn}$ and $\mathrm{Si}$ to the leach solution during zinc refinery residue leaching $\left(\left[\mathrm{H}_{2} \mathrm{C}_{2} \mathrm{O}_{4}\right]=110 \mathrm{~g} / \mathrm{L} ; \mathrm{L} / \mathrm{S}=8 ; \mathrm{t}=30 \mathrm{~min} ;\left[\mathrm{H}_{2} \mathrm{O}_{2}\right]=0.08\right.$ $\mathrm{mol} / \mathrm{L})$.

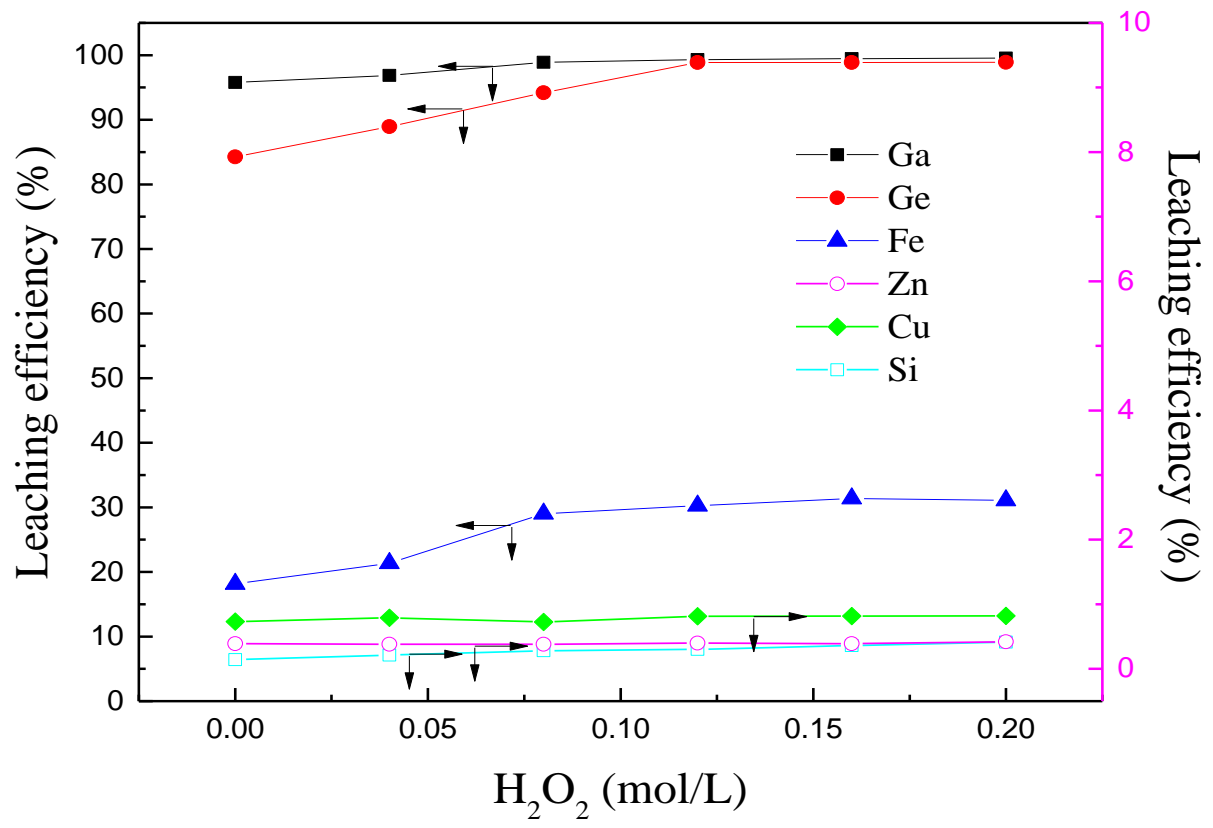

Fig. 10. Effect of $\mathrm{H}_{2} \mathrm{O}_{2}$ concentration on the recovery of $\mathrm{Ga}, \mathrm{Ge}, \mathrm{Fe}, \mathrm{Cu}, \mathrm{Zn}$ and $\mathrm{Si}$ to the leach solution during zinc refinery residue leaching $\left(\left[\mathrm{H}_{2} \mathrm{C}_{2} \mathrm{O}_{4}\right]=110 \mathrm{~g} / \mathrm{L} ; \mathrm{L} / \mathrm{S}=8 ; \mathrm{T}=40{ }^{\circ} \mathrm{C} ; \mathrm{t}=30\right.$ $\min )$. 


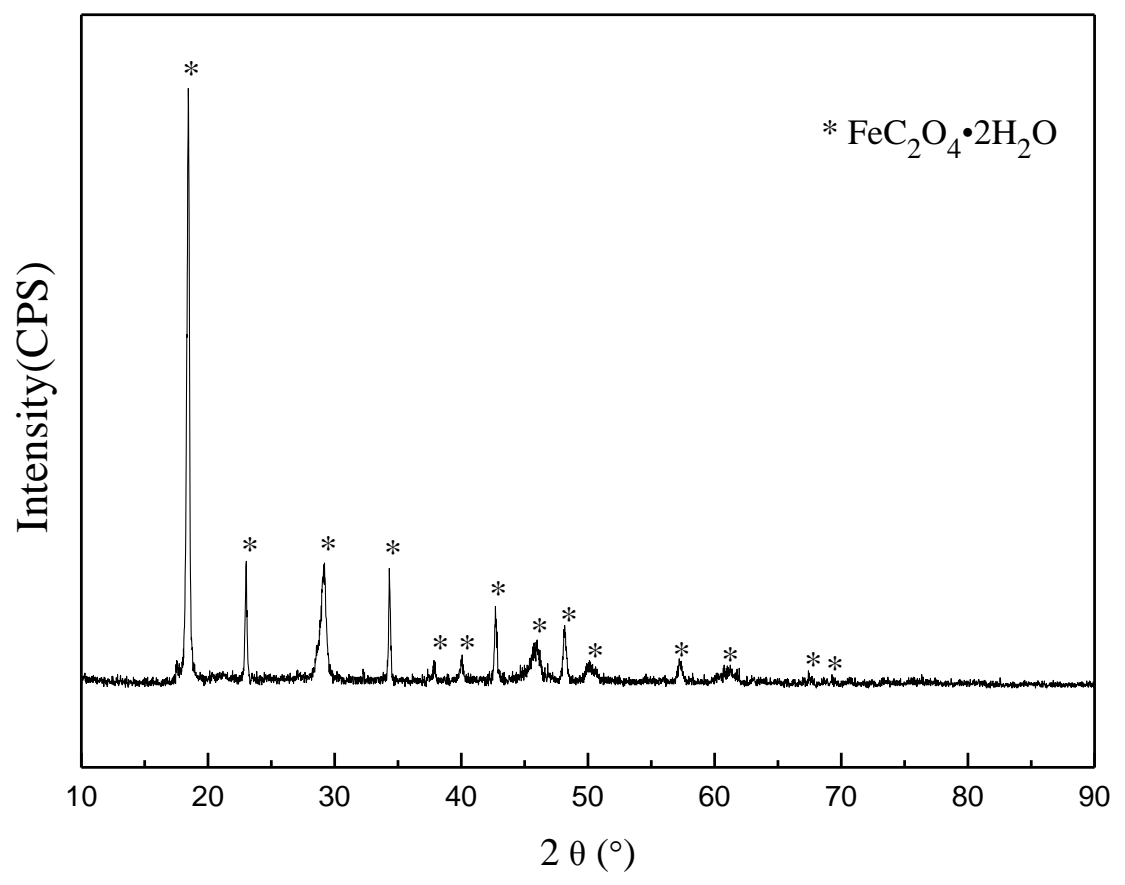

Fig. 11. X-ray diffraction pattern of the residue after iron removal $(\mathrm{Fe} / \mathrm{Fe}(\mathrm{III})=6$; Ultrasound power $=150 \mathrm{~W}$; Ultrasound time $=10 \mathrm{~min} ; \mathrm{T}=50^{\circ} \mathrm{C} ; \mathrm{t}=1 \mathrm{~h}$ ).

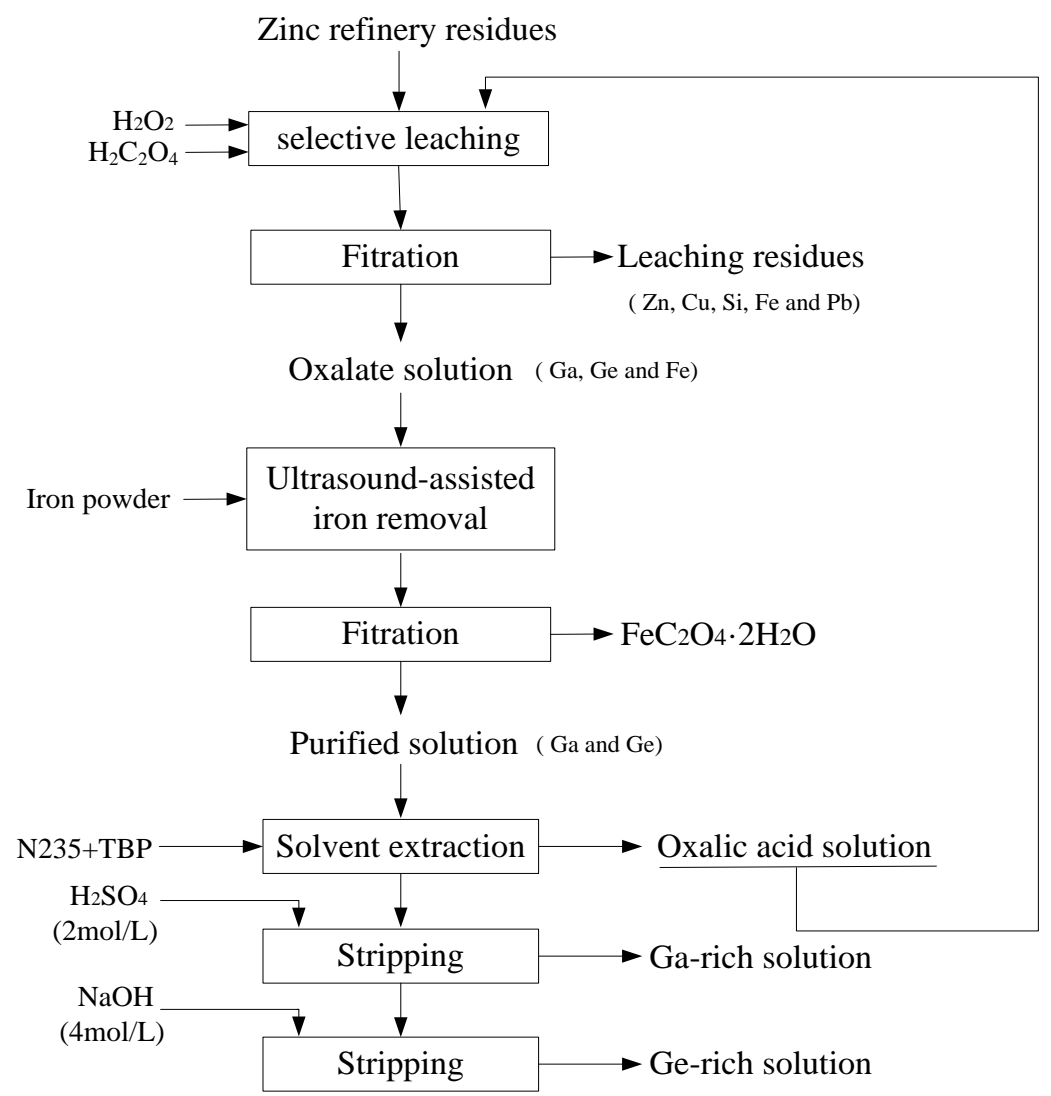

Fig. 12. Process flow sheet for the recovery Ga and Ge from zinc refinery residues. 